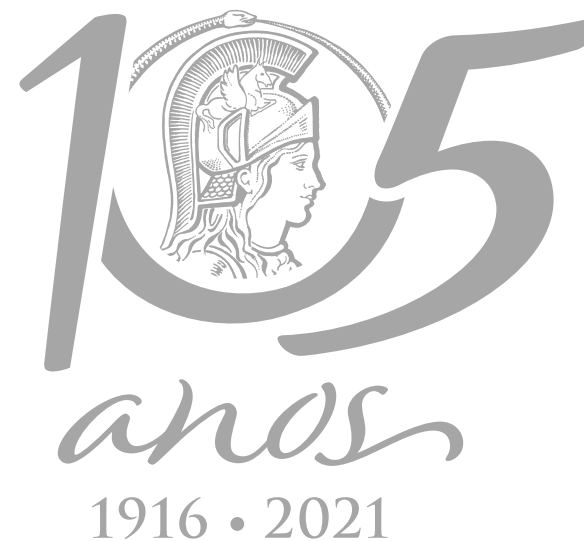

$1916 \cdot 2021$

\title{
ECOSYSTEMS
}

\section{Diatom and Invertebrate Assemblages in High Altitude Saline Wetlands of the Argentinian Puna and their Relation to Environmental Factors}

\author{
MARÍA FLORENCIA COLLA, AGUSTINA INÉS LENCINA \& MARÍA EUGENIA FARÍAS
}

\begin{abstract}
Aquatic biota in high altitude Andean wetlands is exposed to extreme environmental conditions that influence ecological parameters at population and community levels. We analyzed changes in occurrence, taxa richness and relative abundance of diatom and invertebrate assemblages in four saline wetlands located at the same altitude (approx. 3,330 masl), in the Salar de Antofalla (Catamarca, Argentina). Biological samples were taken seasonally during a 1-year period, together with water variables, which were used in ordination techniques to characterize the sites. Water ionic content and biological variables, such as microcrustacean abundance and diatom richness, were evaluated as possible factors affecting the assemblages' distribution. The wetlands ranged from meso- to hyperhaline habitats and showed distinctive morphological, physical and chemical characteristics. Diatoms (42 taxa) and invertebrates (15 taxa) were collected from all sites, and diatom taxa richness was negatively correlated with water conductivity. According to multivariate analysis, the distribution of both communities was significantly explained by water hardness, whereas copepod abundance also influenced the diatom flora. We conclude that, at the same altitude and, consequently, UV radiation exposure, variables related to ionic content and/or biological parameters of the aquatic habitat may act as determinants of the biota distribution in these extreme environments.
\end{abstract}

Key words: biodiversity, central Andes, extremophiles, limnology, Salar de Antofalla.

\section{INTRODUCTION}

The Argentinian Puna plateau is located at altitudes around 4,000 masl, and constitutes the southern termination of the Andean Altiplano (Auge et al. 2006, Ramos 1999). The climate is dry and cold, with precipitations decreasing from north to south and from east to west, occurring mostly during the winter months, as snowfall (Alonso 2006, valero-Garces et al. 2000). Hydrologically, the Puna region consists of a set of endorheic basins, separated by N-S trending ranges and transversal volcanic chains. The main hydrogeological units are represented by free and semi-confined aquifers in modern alluvial fans, whereas Precambrian and early Paleozoic aquifers are placed in the basements rocks (Auge et al. 2006). Climatic conditions (low recharges vs. high evaporation rates) are the main factor limiting freshwater reservoirs in the Puna (Auge et al. 2006, García et al. 2013), and they are important for economic activities such as agriculture, cattle raising and mining. In fact, due to the increasing demand of lithium and potassium worldwide, many salares from the Puna region are being explored (Izquierdo et al. 2015).

High altitude wetlands in the Puna region, although they show varied morphometric and hydrological characteristics, are generally 
shallow environments exposed to high salinity, large thermal fluctuations, high UV radiation, and presence of metalloids, such as arsenic (Ordoñez et al. 2009, Flores et al. 2009, Albarracín et al. 2012). Recently, diverse microbialites deposits organic sedimentary structures formed during the growth and metabolism of microorganisms, especially cyanobacteria (Rishworth et al. 2016), - have been reported covering the shores of high altitude wetlands like the Socompa Lake, in Salta (Farías et al. 2013), and Laguna Negra, in Catamarca (Gómez et al. 2014, 2018). Microbialites comprise the mineralized record of early life on Earth (Gómez et al. 2014), and the existence of modern systems in the Puna has a great ecological importance since they may represent trophic pillars, acting as oxygen sources for the aquatic environment through oxygenic photosynthesis (Farías et al. 2013, Rascovan et al. 2016, Rasuk et al. 2014, 2016).

Due to the extreme environmental conditions, saline wetlands tend to have simple food webs, with fewer trophic levels as salinity increases (Por 1980, Alcorlo et al. 2001). Among eukaryotic photosynthetic organisms, diatoms are common components of saline environments, where they can represent a dominant item in algal biomass (Iltis et al. 1984), and constitute a diverse taxonomic group (Angel et al. 2016). Morphological plasticity has been suggested as an important factor in diatom ecological success in these environments (Leterme et al. 2013). In saline environments of the Andean Altiplano, benthic diatoms play an important role in food webs, and represent the main food resource for two of the three vulnerable or near threatened flamingo species (Bayly 1993, Fernández-Zenoff et al. 2015, Márquez García et al. 2009, IUCN 2019).

On the other hand, aquatic invertebrates are known to be represented by relatively few taxonomic groups in saline wetlands, exhibiting variable abundances, according to the gradients of biotopes with different physical and chemical conditions present (Dejaux 1993, Williams et al. 1995). An important fraction of the invertebrate biomass in saline wetlands of the Puna region is represented by microcrustaceans, like planktonic copepods of the genus Boeckella sp. (Locascio de Mitrovich et al. 2005, MuñozPedreros et al. 2013, 2015). They feed mainly on algae (Moeller et al. 2005), bacteria, detritus and other copepods (Hurlbert et al. 1986) and constitute an important food item for flamingo species (Hurlbert et al. 1986, Bayly 1995, Locascio de Mitrovich et al. 2005). Other important components of saline wetlands biota include larval stages of diptera Chironomidae (MárquezGarcía et al. 2009), Ephydridae (Williams et al. 1995), ostracods, nematodes (Scheihing, et al. 2010), and anostracans (Dejoux 1993, Williams et al. 1995).

Ecological studies in Andean Puna wetlands have focused on archaeal and bacterial communities (Ordoñez et al. 2009, Farías et al. 2013, Rascovan et al. 2016, Rasuk et al. 2014, 2016), algae (Mirande \& Tracanna 2009, Maidana \& Seeligmann 2006, 2015, Seeligmann et al. 2018), zooplankton (Locascio de Mitrovich et al. 2005, Frau et al. 2015), and birds (Caziani \& Derlindati 2000, Caziani et al. 2007). However, most of these studies correspond to punctual samplings, and only few of them provide information about the relation between aquatic biota and environmental variables.

While altitude, UV radiation and salinity/ conductivity have been studied as important environmental pressures in these extreme wetlands, affecting species richness, biomass and/or abundance of algae and invertebrates (Hammer 1986, Williams et al. 1990, Helbling et al. 2006, Mirande \& Tracanna 2009, Sommaruga 2001, Frau et al. 2015, Gutierrez et al. 2018), other environmental factors, like water chemistry, have received less attention. Based on this, we 
attempt to determine the environmental factors that may contribute to diatom and invertebrate distribution, when altitude, and, consequently, UV radiation variables are uniform across the saline wetlands. For this purpose, the Salar de Antofalla was considered as a good study model, since preliminary exploration field campaigns revealed that several salar-associated water bodies were located within a narrow altitudinal range (mean altitude of 3,330 masl).

The objectives of this study were to (1) describe physical, chemical and morphological characteristics of four high altitude wetlands in the Salar de Antofalla; (2) determine diatom and invertebrate assemblages in these wetlands and their seasonal variations during a 1-year period; and (3) identify main environmental variables that significantly affect the distribution of the aquatic biota studied. Given that the wetlands share a close association with the salar, and are located at the same altitude, we expect differences in other aspects, such as aquatic chemistry, which could influence the diatom and invertebrate communities structure. To the best of our knowledge, this work represents the first description of diatom and invertebrate assemblages in wetlands of the Salar de Antofalla.

\section{MATERIALS AND METHODS}

\section{Study area}

Salar de Antofalla (Fig. 1a and b) is one of the largest salt flats in South America, stretching for $\sim 150 \mathrm{~km}$ long, $6 \mathrm{~km}$ wide, and with an average altitude of 3,900 masl (Voss 2002, Izquierdo et al. 2016). It is located in the northwestern Argentinian Puna, between the Andes mountain range and Sierra de Calalaste, in the province of Catamarca (Voss 2002).

\section{Sites description}

Laguna Verde (LV, Fig. 1c) is a small sub-rounded pond, mainly fed with salar brine and evaporitic halite and gypsum deposits covering the claysilt sediments in the bottom and shores. Pozo Bravo (PB, Fig. 1d) has an elongated shape, and homogeneous grayish-blackish microbial mats cover the sandy substratum almost completely. The entire margin of this lake presents microbialites of varied morphology. Ojo de Campo Azul (OCA, Fig.1e) is a rounded pond whose substrate includes sand, silt and gravel covered by aquatic undetermined rooted vegetation in almost all of its extension. A small section at the north of this site presented whitish-pink microbial mats of reduced extension. Finally, Ojos de Campo Naranja (OCN, Fig. 1f) are two different sized water bodies joined into one eight-shaped wetland. The substrate is fine, silty and blackish, and the narrow union area between both wetlands presents lithified microbial mats. The bright orange color of the water is probably due to the presence of pigmented bacteria and/ or algae (Oren 2009).

\section{Sampling and laboratory analysis}

Sampling campaigns were conducted seasonally (May 2017, fall; August 2017, winter; November 2017, spring; and January 2018, summer), in the four previously described aquatic environments at Salar de Antofalla. In each wetland, three littoral sampling sites (marked with dots in embeded images in Figure $1 c, d$, e and f), were selected according to water depth and substrate type. At each sampling site, and in order to represent the spatial variability of each wetland, we collected one benthic replicate for diatom analysis, one benthic replicate for invertebrates analysis, and one planktonic replicate for invertebrates analysis, accounting for a total of 9 samples per lake at each sampling occasion. 


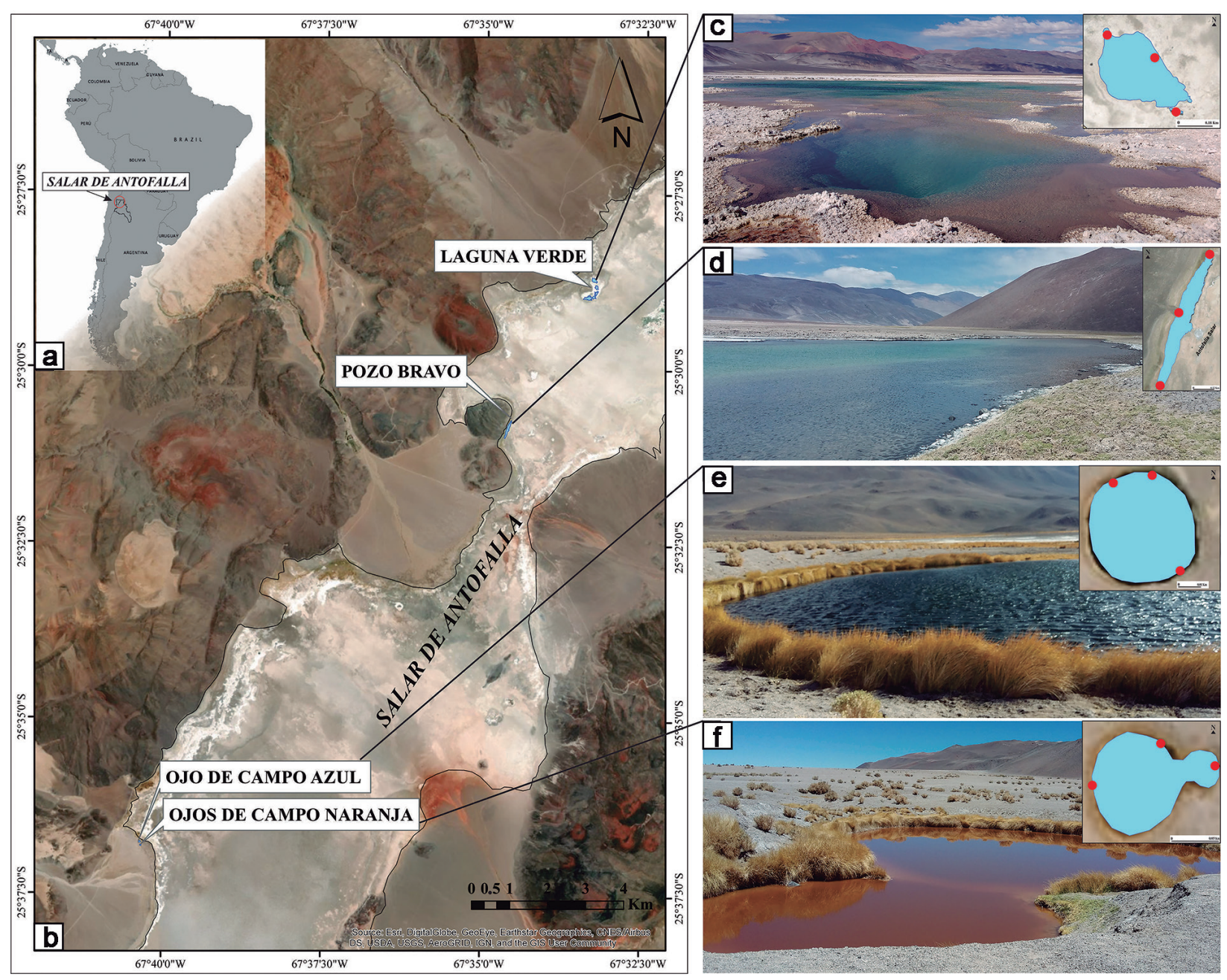

Figure 1. Geographical location of the study area. (a) Location of the Salar de Antofalla in the Catamarca province, Argentina, South America. (b) Location of the four wetlands in the Salar de Antofalla. (c) Laguna Verde (LV). (d) Pozo Bravo (PB). (e) Ojo de Campo Azul (OCA). (f) Ojos de Campo Naranja (OCN). Sampling sites at each wetland are marked with dots in Fig. 1c, d, e and f.

Diatom samples were obtained from the sediment surface (approximately $0-1 \mathrm{~cm}$ sediment depth) of each wetland using a $7 \mathrm{~cm}$ diameter core. The material was fixed in situ with $4 \%(v / v)$ formalin. Samples preparation followed standard procedures involving treatment with $\mathrm{H}_{2} \mathrm{O}_{2}(30 \%)$ for the elimination of organic matter, followed by heating and rinsing the resulting suspension with distillated water until pH was neutral (Battarbee 1986). The samples were dried onto coverslips and permanently mounted using a Naphrax ${ }^{\circledR}$ mounting medium.
A minimum value of 400 frustules per sample was counted using a Leica DM500 microscope at $1000 \times$ magnification, and mean relative frequencies (\%) were calculated. Benthic diatoms were identified to the lowest possible taxonomic level following specialized literature (Round et al. 1990, Kramer 2000, Lange-Bertalot 2000, 2001, Maidana \& Seeligmann 2006, Levkov 2009, Levkov et al. 2013).

Invertebrate samples consisted of two collections for each wetland: a benthic collection formed by 3 replicates extracted with a $7 \mathrm{~cm}$ 
diameter core with a volume of $200 \mathrm{~cm}^{3}$, and a planktonic collection formed by 3 replicates, from the same site, obtained by filtering 100 $L$ of superficial water through a conventional conical plankton net (20 $\mu \mathrm{m}$ mesh size). The material was fixed in situ with 70\% (v/v) ethanol. Benthic samples were completely analyzed with a stereoscopic microscope, and invertebrates were identified to the lowest possible taxonomic level. Planktonic samples were analyzed under a microscope using a SedgwickRafter chamber with $1 \mathrm{ml}$ of capacity, and mean abundance (individuals/l) was calculated. Mean relative frequencies (\%) of the three replicates were obtained for benthic and planktonic invertebrates at each site. Identification of invertebrates followed specialized literature for each group (Brinkhurst 1971, Tarjan et al. 1977, Bayly 1992, Fernández \& Domínguez 2001, Bruno et al. 2005, Schmelz \& Collado 2010).

Geographical coordinates (DMS) and altitude (masl) were measured with GPS, and the area of each wetland was estimated using ArcMapTM 10.6.1 2019 (ArcGIS ${ }^{\circledR}$-ESRI). Superficial water variables, such as temperature $\left(\mathrm{C}^{\circ}\right), \mathrm{pH}$, conductivity $(\mathrm{ms} / \mathrm{cm})$ and dissolved oxygen $(\mathrm{mg} / \mathrm{l})$ were registered seasonally in situ using a HANNA HI 9828 multi-sensor probe. Salinity ( $\mathrm{g} / \mathrm{l}$ ) was estimated from conductivity following Dejaux (1993). Classification of the wetlands according to salinity followed Hammer (1986): subhaline $(0.5-3 \mathrm{~g} / \mathrm{l})$, hypohaline $(3-20 \mathrm{~g} / \mathrm{l})$, mesohaline (20-50 $\mathrm{g} / \mathrm{l})$ and hyperhaline (>50 $\mathrm{g} / \mathrm{l})$. Dissolved oxygen values measured in situ were corrected for salinity, temperature and altitude according to Rounds et al. (2013), and therefore, they must be considered as relative values. As part of the general limnological characterization of the wetlands, temperature and conductivity vertical profiles were also measured at each study site in winter and summer using a sensor with a 10-meter long cable.
Additionally, superficial water samples were taken during winter and summer at all four aquatic environments for chemical analysis. The samples were stored in sterile recipients in the dark and refrigerated $\left(4^{\circ} \mathrm{C}\right)$ until further analysis in laboratory INDUSER, Buenos Aires, Argentina, within 1-2 weeks. The following analyses were performed following APHA (2012) standardized methods. Analyses for chloride, nitrate, sulfate and bromide were performed by ionic chromatography. Total hardness was obtained by calculation method. The analyses for arsenic, lithium, boron, manganese, copper, iron and nickel were performed by microwaveassisted acid digestion and inductively coupled plasma induction/mass spectrophotometry (ICP/MS). Total phosphorus was estimated by digestion methods using the persulfate oxidation technique, and phosphate was determined by colorimetric vanadomolybdophosphoric acid method. Nitrite was estimated by colorimetric method, and ammoniacal nitrogen was calculated by phenate method with a preliminary distillation step into sulfuric acid. Magnesium, potassium, sodium and calcium were calculated using ion chromatography (ISO14911, 1998). Dissolved silica was determined by inductively coupled plasma/optical emission spectrometry (ICP-OES) technique (US. EPA 2015).

\section{Data analysis}

To test for differences between the annual mean values of the four water variables measured in situ at each study, an Analysis of Variance (ANOVA) with a post-hoc Bonferroni test $(p<0.05)$ was conducted. Variables used in ANOVA were previously analyzed for normality (Shapiro-Wilk; $p<0.05)$. All physical and chemical variables (except $\mathrm{pH}$ ) were log transformed $\left(\log _{10} x+1\right)$ prior to the statistical treatment, since they differed in several orders of magnitude. Chemical variables measured in laboratory were analyzed 
for significant correlations (Pearson, r; $p<0.05$ ), using the SPSS v. 22.0 software.

A Principal Component Analysis (PCA) was conducted in order to analyze the relation between the environmental variables measured in situ, and to characterize the study sites. The analysis was performed with the PAST V3.25 software (Hammer et al. 2001), and included the seasonal values of water temperature $\left({ }^{\circ} \mathrm{C}\right)$, $\mathrm{pH}$, conductivity $(\mathrm{ms} / \mathrm{cm})$ and dissolved oxygen content ( $\mathrm{mg} / \mathrm{l})$.

Species richness, expressed as taxa number, was obtained for diatoms and invertebrates at each site and season. In order to evaluate the relations between taxa richness and the four variables measured in situ, the non-parametric Spearman correlation coefficient (rho; $p<0.05$ ) was calculated using the SPSS v. 22.0 software. The Non-Metric Multidimensional Scaling (NMS), based on Jaccard's Similarity Index (for presence/absence data), was used to ordinate samples in two dimensions based on diatom and invertebrate communities structure (Lepš \& Šmilauer 2003). Analysis of similarities (ANOSIM) was used to identify significant differences between assemblages belonging to the four wetlands. Both analysis (NMS and ANOSIM) were performed using the PAST software. ANOSIM R statistics were interpreted according to Clarke et al. (2014): large values (close to unity) are indicative of complete separation of the groups, small values (close to zero) indicate little or no segregation.

At each study site, relative frequencies (\%) of diatoms and invertebrates were calculated in two contrasting seasons, winter and summer. For statistical analysis, numerical biological data were square root transformed in order to stabilize the variances, and to downweight for rare taxa. Diatom and invertebrate relative frequencies were considered separate response variables in multivariate analysis. For the selection of the explanatory variables, the original dataset of 21 chemical variables measured in laboratory was reduced to 12 after the extraction of those with values under the measurement detection limit, such as total phosphorus, nitrite, phosphate, etc. If the chemical variables were mutually correlated (Pearson; $p<0.05$ ), like chloride and sodium, hardness and calcium, etc., only one of them was included in the analysis.

In order to determine the length of the environmental gradients and decide if linear or unimodal methods were applicable to analyze the data, a preliminary Detrending Correspondence Analysis (DCA) was performed for each biological data set (frequencies of diatoms and invertebrates, separately). Since the length of environmental gradients was $>3$ standard deviations in both analyses, a Canonical Correspondence Analysis (CCA) was chosen to interpret the environmental factors that could act as predictors of the diatom and invertebrate community composition (Lepš \& Šmilauer 2003). Both analyses were performed with the CANOCO ${ }^{\circ}$ software for Windows v. 4.5. (ter Braak \& Šmilauer 1998). Before running the CCA, a forward selection of 14 variables was conducted with 12 water chemical variables (highlighted in bold in Table II), water temperature and maximum depth of the aquatic environment. For the diatom community, two biological variables were also added: copepod abundance (Harpacticoidea + Calanoidea) and Artemia sp. abundance, both square root transformed; whereas for the invertebrate community, the diatom richness variable was included. The significance of each potential predictor was assessed by means of a Monte Carlo permutation test calculated by randomly sampling 499 permutations under a reduced model (Lepš \& Šmilauer 2003). The variables included in the CCA were those that better explained the variation in the composition of each biological 
dataset (diatoms and invertebrates), and those with low variance inflation factors (VIF $<10$ to avoid multicollinearity).

\section{RESULTS}

\section{Environmental characteristics of the wetlands}

The main environmental characteristics of the study sites together with four water variables measured in situ (mean annual values \pm standard deviation) are summarized in Table I. In general, pH was neutral to slightly alkaline, and mean values showed statistically significant differences between LV and OCA ( $F=3.86 ; \mathrm{p}<0.038$ ). OCA registered the highest values for dissolved oxygen compared with the other sites ( $F=26.45$; $p<0.000014)$, and the lowest mean conductivity $(\mathrm{F}=36.9 ; \mathrm{p}<0.000002)$. According to this variable, the environments analyzed are classified as hyperhaline (salinity >50 $\mathrm{gr} / \mathrm{l}$ ) except for OCA, which can be considered mesohaline (salinity between 20-50 g/l) (Dejaux 1993). Conductivity and dissolved oxygen values were negatively correlated $\left(r=-0.919 ; p=4.93{ }^{*} 10^{-7}\right)$.

The PCA showed that components 1 and 2 accounted for $78.45 \%$ of the data variability (C1: $46.26 \%$ and C2: 32.19\%, Fig. 2). Component 1 reflects the variability in water conductivity and $\mathrm{pH}$. Samples located on the left side of this component had higher conductivity values and lower pH. Samples located near the center of the graph had intermediate values for the four variables measured, like OCN in fall and winter, and PB in winter, spring and summer. The fall sample from this site was located separately because of its high $\mathrm{pH}$ value registered at this season (9.6). In OCA, the four seasonal samples were related to alkaline, less saline waters and higher dissolved oxygen content.

The analysis of the vertical profiles in the four study sites showed that in LV (Fig. 3a), a thermocline and halocline were registered only in the deepest part of this environment $(2.5 \mathrm{~m})$ during winter. In summer, temperature values increased at bottom depth, while conductivity decreased. However, the changes were more gradual than in winter, and no thermo- or halocline were registered. Sites PB (Fig. 3b) and OCA (Fig. 3C) presented thermal and saline vertical homogeneity, with subtle variations of both variables in the water column. Finally, OCN (Fig. 3d) registered thermal and saline stratification during both seasons studied.

The water ionic composition of the four environments showed that all of them were sodic-chlorinated $\left(\mathrm{Na}^{+}>\mathrm{K}^{+}, \mathrm{Ca}^{2+}\right.$ and $\mathrm{Mg}^{2+} ; \mathrm{Cl}^{-}>$ $\mathrm{SO}_{4}{ }^{2-}$ ) (Table II). Regarding the cations, the water of OCA and OCN showed a higher concentration of potassium than calcium and magnesium in winter and summer, whereas in the LV and PB lagoons, calcium was the second important cation after sodium. Water ionic content was different between OCA and OCN, with higher values for total hardness and boron in OCN. With respect to nutrients, the levels of total phosphorous (TP) were below the detection limit $(0.10 \mathrm{mg} / \mathrm{l})$ in the four study sites, whereas nitrate was the predominant form of inorganic nitrogen, and ranged from below detection limit (5.0 $\mathrm{mg} / \mathrm{l}$ ) to $670 \mathrm{mg} / \mathrm{l}$.

\section{Diatom and invertebrate occurrence and taxa richness}

Forty-two diatom taxa were recorded in the 48 benthic samples collected from the four high altitude aquatic environments. The seasonal occurrence of taxa and taxa richness per study site are presented in Supplementary Material - Table SI. Diatom taxa richness was negatively correlated with water conductivity (rho $=-0.66$, $p<0.01$ ). The NMS ordination of the seasonal samples of each wetland, based on diatom assemblages structure, is presented in Figure 4a. The diatom composition showed differences 
Table I. Geographical coordinates, morphological variables and aquatic parameters measured at each study site of the Salar de Antofalla, Catamarca. Classification of the wetlands according to salinity followed Hammer (1986). Range, mean and standard deviation (SD) of four seasonal aquatic variables are presented $(n=4)$. Values with at least one letter in common did not differ statistically (ANOVA; Bonferroni post-hoc test; $p>0.05$ ).

\begin{tabular}{|c|c|c|c|c|}
\hline & $\begin{array}{l}\text { Laguna Verde } \\
\text { (LV) }\end{array}$ & $\begin{array}{l}\text { Pozo Bravo } \\
\text { (PB) }\end{array}$ & $\begin{array}{l}\text { Ojo de Campo Azul } \\
\text { (OCA) }\end{array}$ & $\begin{array}{c}\text { Ojos de Campo Naranja } \\
\text { (OCN) }\end{array}$ \\
\hline DMS Coordinates & $\begin{array}{l}25^{\circ} 28^{\prime} 43.66^{\prime \prime} \mathrm{S} \\
67^{\circ} 33^{\prime} 16.25^{\prime \prime} \mathrm{W}\end{array}$ & $\begin{array}{l}25^{\circ} 30^{\prime} 58.20^{\prime \prime} \mathrm{S} \\
67^{\circ} 34^{\prime} 41.33^{\prime \prime} \mathrm{W}\end{array}$ & $\begin{array}{l}25^{\circ} 36^{\prime} 44.87^{\prime \prime} \mathrm{S} \\
67^{\circ} 40^{\prime} 21.84^{\prime \prime} \mathrm{W}\end{array}$ & $\begin{array}{l}25^{\circ} 36^{\prime} 48.14^{\prime \prime} \mathrm{S} \\
67^{\circ} 40^{\prime} 19.82^{\prime \prime} \mathrm{W}\end{array}$ \\
\hline Altitude (masl) & 3,334 & 3,327 & 3,331 & 3,332 \\
\hline Lake area $\left(\mathrm{m}^{2}\right)$ & 10,132 & 21,108 & 1,813 & 834.9 \\
\hline Maximum depth (m) & 2.5 & 2.5 & 7 & 2.5 \\
\hline $\begin{array}{l}\text { Mean annual salinity }(\mathrm{g} / \mathrm{l}) \\
\text { Classification of the water }\end{array}$ & $\begin{array}{c}176.26 \\
\text { Hyperhaline }\end{array}$ & $\begin{array}{c}140.69 \\
\text { Hyperhaline }\end{array}$ & $\begin{array}{c}27.9 \\
\text { Mesohaline }\end{array}$ & $\begin{array}{c}149.6 \\
\text { Hyperhaline }\end{array}$ \\
\hline $\begin{array}{c}\text { Temperature }\left({ }^{\circ} \mathrm{C}\right) \\
\text { Range } \\
\text { Mean (SD) }\end{array}$ & $\begin{array}{c}7-26.4 \\
16.2(10.17) \mathbf{a}\end{array}$ & $\begin{array}{c}8.76-23 \\
15.16(7.36) \mathbf{a}\end{array}$ & $\begin{array}{c}4.7-27.3 \\
14.82(11.17) \mathbf{a}\end{array}$ & $\begin{array}{c}4.4-29.6 \\
15.82(12.55) \mathbf{a}\end{array}$ \\
\hline $\begin{array}{c}\text { pH } \\
\text { Range } \\
\text { Mean (SD) }\end{array}$ & $\begin{array}{c}7.31-8.01 \\
7.54(0.31) \mathbf{a}\end{array}$ & $\begin{array}{c}7.84-9.6 \\
8.37(0.82) \mathbf{a b}\end{array}$ & $\begin{array}{c}8.45-8.75 \\
8.57(0.13) \mathbf{b}\end{array}$ & $\begin{array}{c}7.78-8.32 \\
7.99(0.23) \mathbf{a b}\end{array}$ \\
\hline $\begin{array}{c}\text { Dissolved oxygen }(\mathrm{mg} / \mathrm{l}) \\
\text { Range } \\
\text { Mean (SD) }\end{array}$ & $\begin{array}{c}0.09-0.38 \\
0.23(0.13) \mathbf{a}\end{array}$ & $\begin{array}{c}0.61-0.72 \\
0.65(0.04) \mathbf{a}\end{array}$ & $\begin{array}{c}1.07-1.89 \\
1.52(0.37) \mathbf{b}\end{array}$ & $\begin{array}{c}0.11-0.62 \\
0.33(0.22) \mathbf{a}\end{array}$ \\
\hline $\begin{array}{c}\text { Conductivity }(\mathrm{mS} / \mathrm{cm}) \\
\text { Range } \\
\text { Mean (SD) }\end{array}$ & $\begin{array}{c}199.1-216 \\
207.37(9.06) \mathbf{a}\end{array}$ & $\begin{array}{c}150-184.9 \\
165.42(17.35) \mathbf{a}\end{array}$ & $\begin{array}{c}30.10-34.20 \\
32.82(1.84) \mathbf{b}\end{array}$ & $\begin{array}{c}108-215 \\
176(46.78) \mathbf{a}\end{array}$ \\
\hline
\end{tabular}

between the groups formed by the seasonal samples of each wetland, according to the ANOSIM results (Global R-statistic $=0.786, p=$ 0.0001), and visualized by convex hulls in the Fig. 4a. Pairwise comparisons were significant in all cases $(p<0.05)$ and showed differences in species communities among all wetlands, with the minimum dissimilarities found between LV and $P B(R=0.6)$ and the maximum between $L V$ and OCA's assemblages $(R=1)$.

With respect to aquatic invertebrates, fifteen taxa, considering planktonic and benthonic organisms, were registered during the study period at the four aquatic environments (Table SII). The NMS ordination, based on invertebrates taxa composition, showed that some samples of the same wetland had identical scores due to uniform fauna (Fig. 4b). The invertebrates communities were different comparing the four study sites, as revealed by the results of the ANOSIM test (Global R-statistic $=0.925, p=0.0001$ ) All pairwise comparisons were significant $(p<0.05)$ with minimum dissimilarities in the species composition between LV and PB $(R=0.8)$, and major differences between OCA and all the other sites ( $\mathrm{R}=1$ for all cases). 


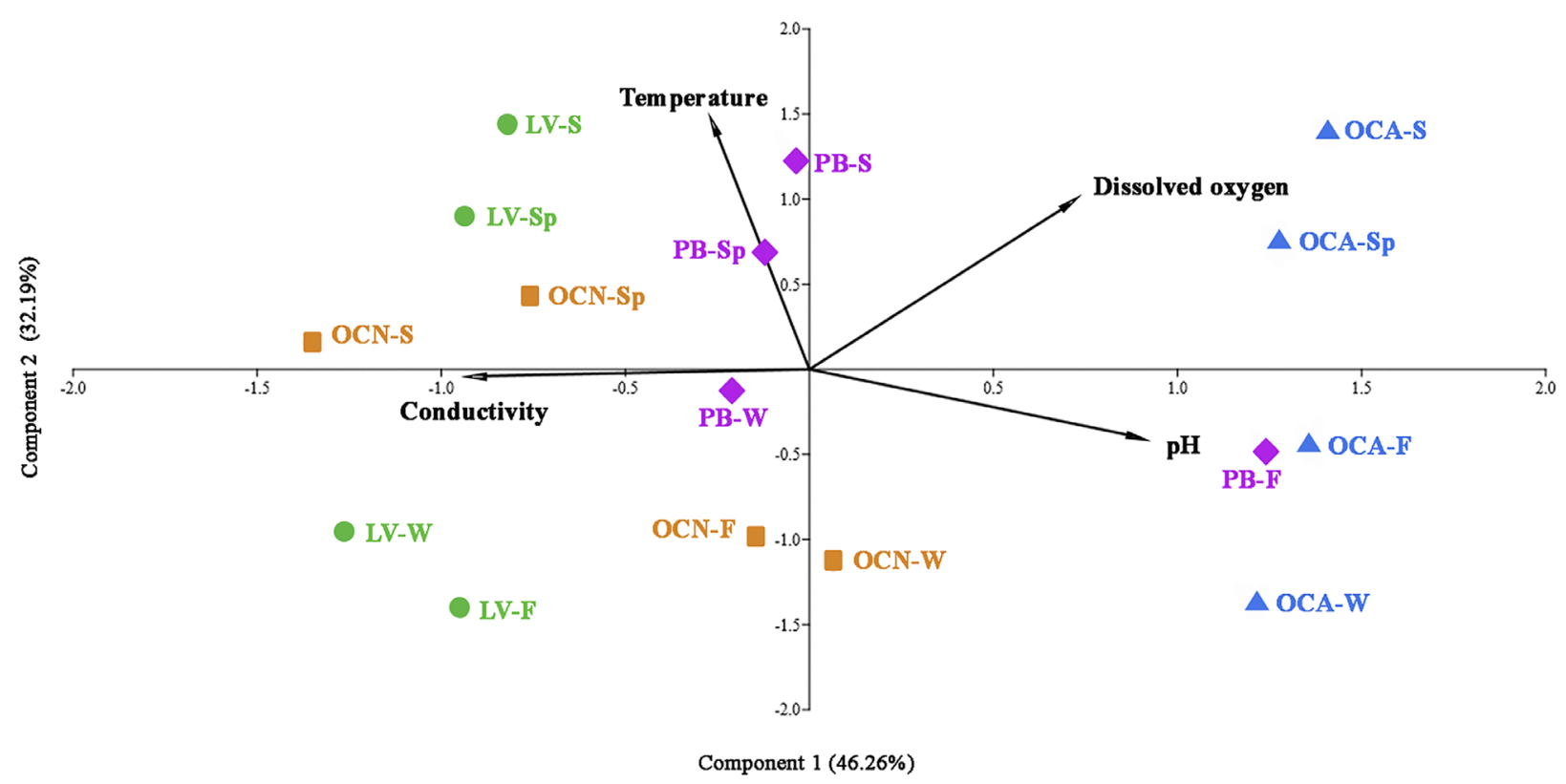

Figure 2. Principal Component Analysis biplot. Variables: Temperature $\left({ }^{\circ} \mathrm{C}\right), \mathrm{pH}$, Dissolved Oxygen $(\mathrm{mg} / \mathrm{l})$, Conductivity (mS/cm). LV: Laguna Verde; PB: Pozo Bravo; OCA: Ojo de Campo Azul; OCN: Ojos de Campo Naranja. F: fall; W: winter; Sp: spring; S: summer.

\section{Diatom and invertebrate abundance and seasonal variation}

Considering the complete data set of diatom taxa collected, 3 genera accounted for $84.64 \%$ of the total abundance (relative frequencies): Halamphora (38.05\%), Nitzschia (33.07\%) and Navicula (13.50\%). The remaining taxa had frequencies oscillating between $0.05 \%$ (e.g. Caloneis) and $6.7 \%$ (Cocconeis). The three most frequent diatom genera also presented the highest species richness; Nitzschia was represented with 12 species; Navicula, with 10; and Halamphora, with 4 (Supplementary Material-Table SI).

Species relative frequencies varied between study sites and seasons. In Laguna Verde, Halamphora coffeaeformis and Nitzschia sp. 5 were the best represented species in both seasons. The diatom community structure of PB was dominated by Halamphora sp., with Halamphora coffeaeformis representing 49.32\% of the total abundance in winter, followed by
Nitzschia epithemoides var. epithemoides. In summer, a variation in the community structure of this lake was registered, with dominance of Halamphora carvajaliana and Craticula molestiforme. The taxa with least numerical representation included seven species of Nitzschia. In OCA, the most frequent species in both seasons was Cocconeis placentula. Several taxa were exclusively registered in OCA (Table SI). Finally, in OCN, Navicula salinicola var. salinicola accounted for the highest frequency during winter, followed by Nitzschia sp. 7 and Navicula sp. 2. During the summer months, Nitzschia sp. 5 dominated numerically. Nitzschia sp. 9 was the only species registered in the four seasons at this site, although with low frequencies.

Regarding taxa composition of invertebrates, the benthic fauna of all sites, except for OCA, was represented by few taxa. Nematoda of the Order Monhysterida were numerically dominant in LV during both seasons analyzed. The immature stages of Dimecoenia sp. (Ephydridae) accounted 

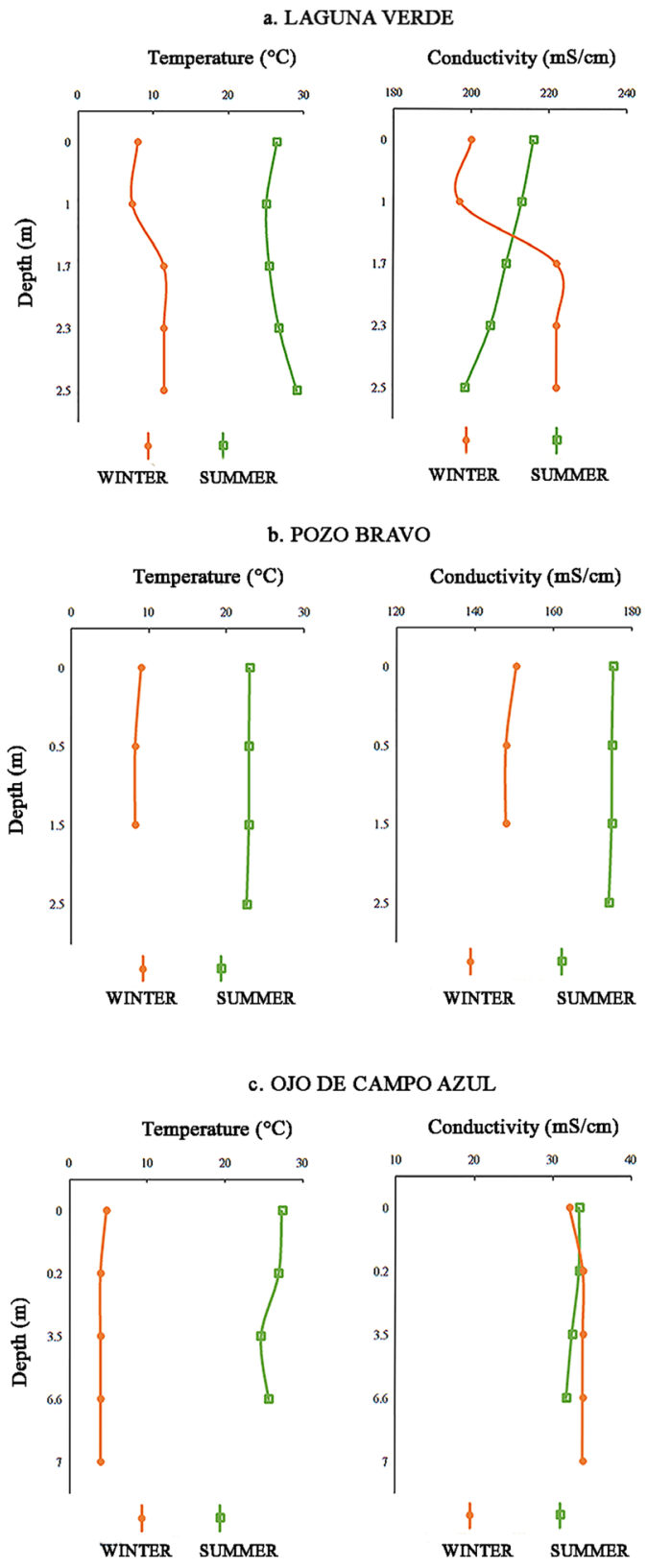

d. OJOS DE CAMPO NARANJA
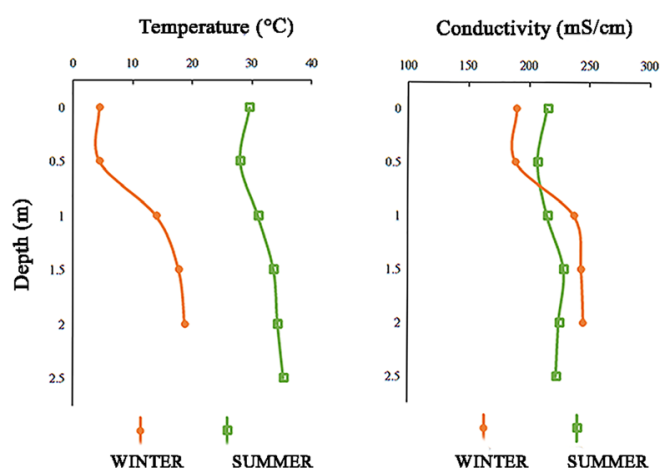

Figure 3. Vertical temperature $\left({ }^{\circ} \mathrm{C}\right)$ and conductivity $(\mathrm{mS} / \mathrm{cm})$ profiles in winter and summer in (a) Laguna Verde, (b) Pozo Bravo, (c) Ojo de Campo Azul and (d) Ojos de Campo Naranja.

for more than $97 \%$ of representation in both seasons at $\mathrm{PB}$, and this was the only taxon registered in the benthos of OCN. On the other hand, benthic composition and distribution in OCA differed between seasons, and some taxa were exclusively found at this site, like three nematode genera, the oligochaete Lumbricillus, larval stages of Ceratopogonidae (Diptera), ostracods and Acari (Table SII).

Planktonic invertebrate taxa were less diverse than benthonic taxa. Artemia sp. was the only microcrustacean present at three of the four environments studied, although with very variable abundances. In PB, a well-developed population was present during all seasons, whereas in OCN, Artemia sp. was present during the year, except in winter. A population peak of this microcrustacean was notable during spring at this site, with mean densities of 18 ind/l; this value decreased in summer. The bright red-pigmented calanoid copepod Boeckella poopoensis was the main planktonic species in OCA, with a constant occurrence during the year and population mean densities of $36.3 \mathrm{ind} / \mathrm{l}$ and 150 ind/l in winter and summer, respectively. Planktonic foraminifers were found in OCA and OCN, with low abundances (Table SII).

\section{Distribution of diatom and invertebrate communities and main environmental variables}

In order to analyze the distribution of diatoms according to the environmental characteristics, a CCA was conducted with the variables selected by the Monte Carlo test, as the best predictors of the variability in diatom composition. We 
Table II. Main chemical water variables $(\mathrm{mg} / \mathrm{l}$ ) of the four high altitude wetlands analyzed in winter (W) and summer (S). Variables selected for statistical analysis are marked in bold.

\begin{tabular}{|c|c|c|c|c|c|c|c|c|}
\hline & \multicolumn{2}{|c|}{ Laguna Verde } & \multicolumn{2}{|c|}{ Pozo Bravo } & \multicolumn{2}{c|}{ ojo de Campo Azul } & \multicolumn{2}{|c|}{$\begin{array}{c}\text { 0jos de Campo } \\
\text { Naranja }\end{array}$} \\
\hline & W & S & W & S & W & S & W & S \\
\hline Chloride & 122000 & 141300 & 78200 & 100620 & 13200 & 13030 & 103000 & 129400 \\
\hline Total hardness & 11600 & 10930 & 8460 & 10250 & 621 & 574 & 2800 & 3840 \\
\hline Phosphate & $<3.0$ & $<3.0$ & $<3.0$ & $<3.0$ & $<3.0$ & $<3.0$ & $<3.0$ & $<3.0$ \\
\hline Nitrate & 670 & 233 & $<5.0$ & $<5.0$ & 32.9 & 36.3 & 335 & 31.9 \\
\hline Nitrite & $<0.02$ & $<0.02$ & $<0.02$ & $<0.02$ & $<0.02$ & $<0.02$ & $<0.02$ & $<0.02$ \\
\hline Ammoniacal nitrogen & $<0.05$ & $<0.05$ & $<0.05$ & $<0.05$ & $<0.05$ & $<0.05$ & $<0.05$ & $<0.05$ \\
\hline Sulphate & 6490 & 5670 & 1920 & 1840 & 264 & 213 & 575 & 242 \\
\hline Arsenic & 0.550 & 1.54 & 0.074 & 0.86 & 0.098 & 0.18 & 0.202 & 0.81 \\
\hline Calcium & 2120 & 1610 & 1570 & 1910 & 103 & 74.6 & 387 & 560 \\
\hline Lithium & 63.5 & 145 & 21.3 & 101 & 15.6 & 20.5 & 92.4 & 277 \\
\hline Total phosphorus & $<0.10$ & $<0.10$ & $<0.10$ & $<0.10$ & $<0.10$ & $<0.10$ & $<0.10$ & $<0.10$ \\
\hline Magnesium & 1520 & 1680 & 1100 & 1330 & 88.6 & 82.9 & 446 & 590 \\
\hline Potassium & 1420 & 1630 & 990 & 1140 & 420 & 384 & 3730 & 4700 \\
\hline Sodium & 72600 & 86200 & 45100 & 57500 & 7830 & 7640 & 59200 & 77950 \\
\hline Bromide & $<0.5$ & $<0.5$ & $<0.5$ & $<0.5$ & $<0.5$ & $<0.5$ & $<0.5$ & $<0.5$ \\
\hline Boron & 71.4 & 214 & 10.5 & 152 & 13.0 & 28.3 & 53.0 & 227 \\
\hline Iron & $<0.10$ & 0.22 & $<0.10$ & 0.33 & $<0.10$ & $<0.10$ & $<0.10$ & 0.32 \\
\hline Manganese & 0.89 & 1.3 & $<0.05$ & 0.6 & $<0.05$ & $<0.03$ & 1.31 & 1.8 \\
\hline Copper & 0.33 & $<0.001$ & 0.24 & $<0.001$ & 0.18 & 0.005 & 0.051 & 0.051 \\
\hline Dissolved Silica & 98.5 & 123 & 83.2 & 158 & 41.2 & 46.2 & 26.7 & 145 \\
\hline Nickel & 0.043 & 0.042 & 0.051 & 0.095 & 0.010 & $<0.010$ & 0.039 & 0.030 \\
\hline
\end{tabular}

selected a model with four of the sixteen variables considered in the forward selection of variables analysis (see Materials and Methods), since they explained most of the variability in species data: hardness, abundance of copepods, si content in water, and water temperature. Only two of these variables were significantly related to the distribution of the species when the 0.05 probability threshold level for entry of a variable was adopted: hardness ( $F=2.11$; $p=0.002)$ and abundance of copepods ( $F=2.10$; $p=0.02$ ). However, we included all four variables in the model since they were independent from the other variables (inflation factors $<10$ ), and contributed to a better interpretation of the diatom assemblages distribution.

The model selected explained $70.84 \%$ of the variability in the frequencies of the diatom taxa ( $F=1.822 ; p=0.024)$, with the first and second axis accounting for $27.2 \%$ and $50.9 \%$ of the variability of species data, and $38.4 \%$ and $71.8 \%$ of the species-environment relation, respectively. According to the first axis, the frequencies of diatom taxa located in the right side of the graph, such as Nitzschia epithemoides var. epithemoides and Nitzschia sp. 5 were associated with water 


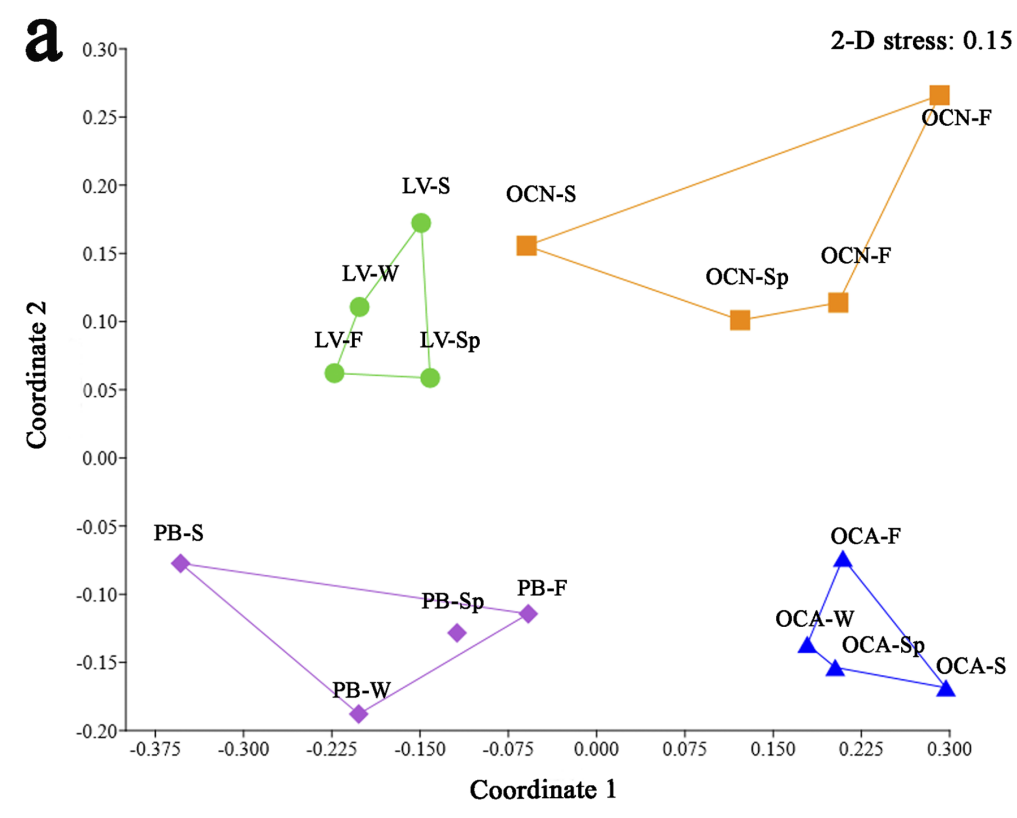

Figure 4. Non-Metric Multidimensional Scaling ordination (NMS, Jaccarad's Similarity Index) of (a) diatom community and (b) invertebrate communituy in four aquatic environments. Convex hulls delineate the groups of seasonal samples of each wetland. LV: Laguna Verde; PB: Pozo Bravo; OCA: Ojo de Campo Azul; OCN: Ojos de Campo Naranja. F: fall; W: winter; Sp: spring; S: summer.

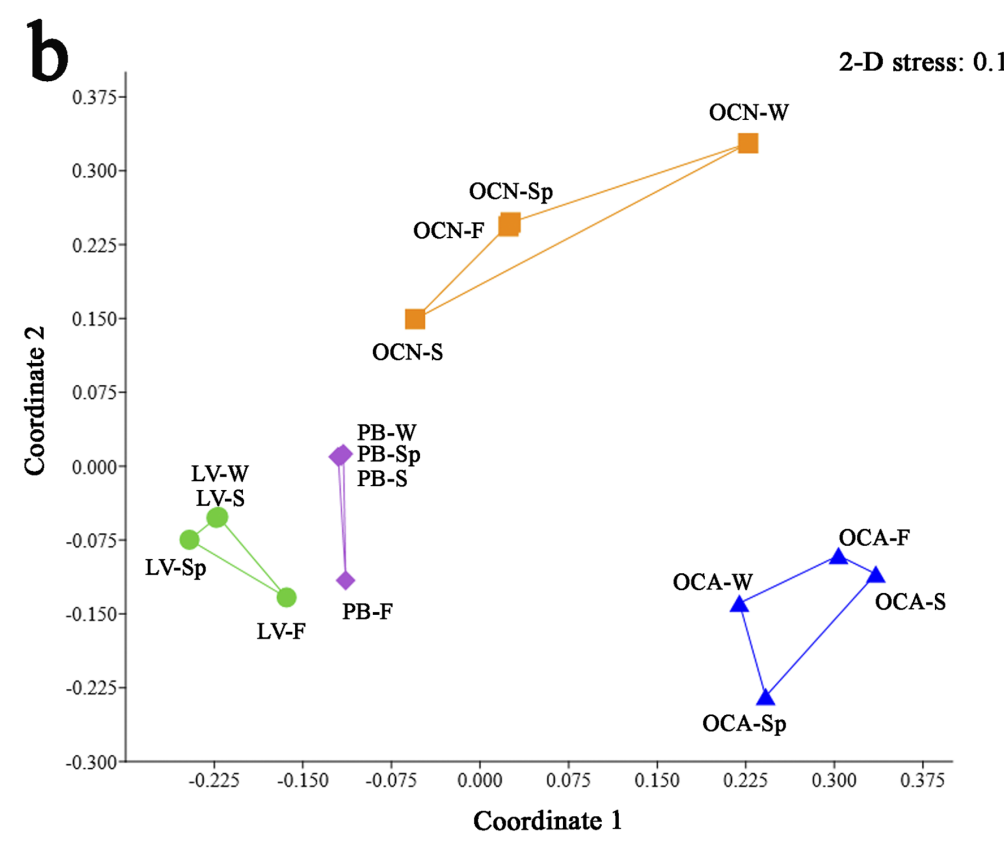

hardness and higher si content in water. On the contrary, the frequencies of taxa such as Cocconeis placentula, Navicula atacamana, Navicymbulla pusilla, Microcostatus sp.1, and Halamphora atacamana were located in the left side of the graph, and related to aquatic environments with less ionic content and with abundance of copepods. Finally, species such as Nitzschia bulnheimiana, Rhopalodia sp. 3 and Nitzschia sp. 7 were frequent in OCN during winter, and associated with colder waters and low abundance of copepods. The species located near the center of the graph were associated with intermediate values of these variables. The diatom taxa with the same species weight (and, therefore, displayed in the same species 
point in the graph) were grouped together and named group 1, 2 and 3 for better interpretation of the triplot. Group 1 includes Nitzschia sp. 1, sp. 2, sp. 3, sp. 4 and sp. 6; Navicula salinicola var. boliviana and Denticula kuestzingii. Group 2 contains Mastogloia sp. 1; Rhopalodia sp. 2, Fragilarioides, Navicula veneta, N. parinacota; Nitzschia hungárica, Achnantes sp 1; Craticula cuspidate var gracilis; Caloneis westii and Frankophila sp 1. Group 3 is represented by Navicula sp. 1, sp. 2 sp. 3 and sp. 4 and Denticula sp. 1.

For invertebrates, the model selected designated three variables as the best predictors of the variability in taxa composition: hardness, diatom richness and nitrate content in water, being hardness the only variable significantly related to the distribution of the species ( $F=3.04 ; p=0.002)$. As with diatoms, we included all the variables in the analysis for a better understanding of the species ordination. The CCA explained $62.57 \%$ of the variation in the frequencies of the invertebrate taxa ( $F=2.229$; $p=0.0080$ ), with the first and second axis accounting for $33.9 \%$ and $54.2 \%$ of the variability of species data, and $54.2 \%$ and $86.7 \%$ of the species-environment relation, respectively.

The CCA triplot (Fig. 5b) showed that the taxa located in the lower right quadrant of the graph, such as Monhysterida nematodes, were related to waters with high content of nitrate. On the other hand, those taxa located in the left quadrant of the graph were associated with aquatic environments with high diatom richness and low water hardness, such as Boeckella poopoensis, Lumbricillus sp., among others. Taxa located near the center of the graph were related to intermediate hardness and diatom richness values, like the values registered in the two remaining sites, PB and OCN. These sites were mainly separated by their nitrate content, according to the gradient of the second axis.
Finally, taxa such as Artemia sp., Harpacticoidea and Dimecoenia sp. tend to occur with higher relative frequencies in waters with low nitrate content.

\section{DISCUSSION}

\section{Environmental characteristics of sites}

The range of abiotic variables registered in the four sites of the Salar de Antofalla was coincident with the environmental characterization of other high altitude lakes of the Argentinian Puna region. They are meso- to hyperhaline, frequently alkaline waters, with variable values of superficial dissolved oxygen (Locascio de Mitrovich et al. 2005, Maidana \& Seeligmann 2006, 2015, Frau et al. 2015, Mirande \& Tracanna 2017). Regarding this last variable, it has long been known that water loses its ability to absorb and hold oxygen as salinity increases, hence saline lakes tend to have low dissolved oxygen concentration (Cole 1983, Hammer 1986, Jakher et al. 1990, Oren 2001). Low oxygen values, like those we report here, were found in similar environments in salt flats from Chile, like the Tebenquiche Lake $(0.6 \mathrm{mg} / \mathrm{l})$ and Colorada Lake (1.96 mg/l) (Zúñiga et al. 1991, Angel et al. 2016) and in the Diamante Lake, inside the Galan Volcano, Catamarca, at 4,600 masl (Maidana \& Seeligmann 2015).

According to the Principal Component Analysis, the four high altitude aquatic environments had distinctive physical and chemical water characteristics, with OCA being clearly different from the other sites, because of its greatest dissolved oxygen content and mesohaline waters. In addition, it presented a homogeneous thermal and saline vertical profile, despite its greater depth. According to Hammer (1986), in saline lakes, mean depths required for thermal stratification vary inversely as salinity. Therefore, less saline waters require 


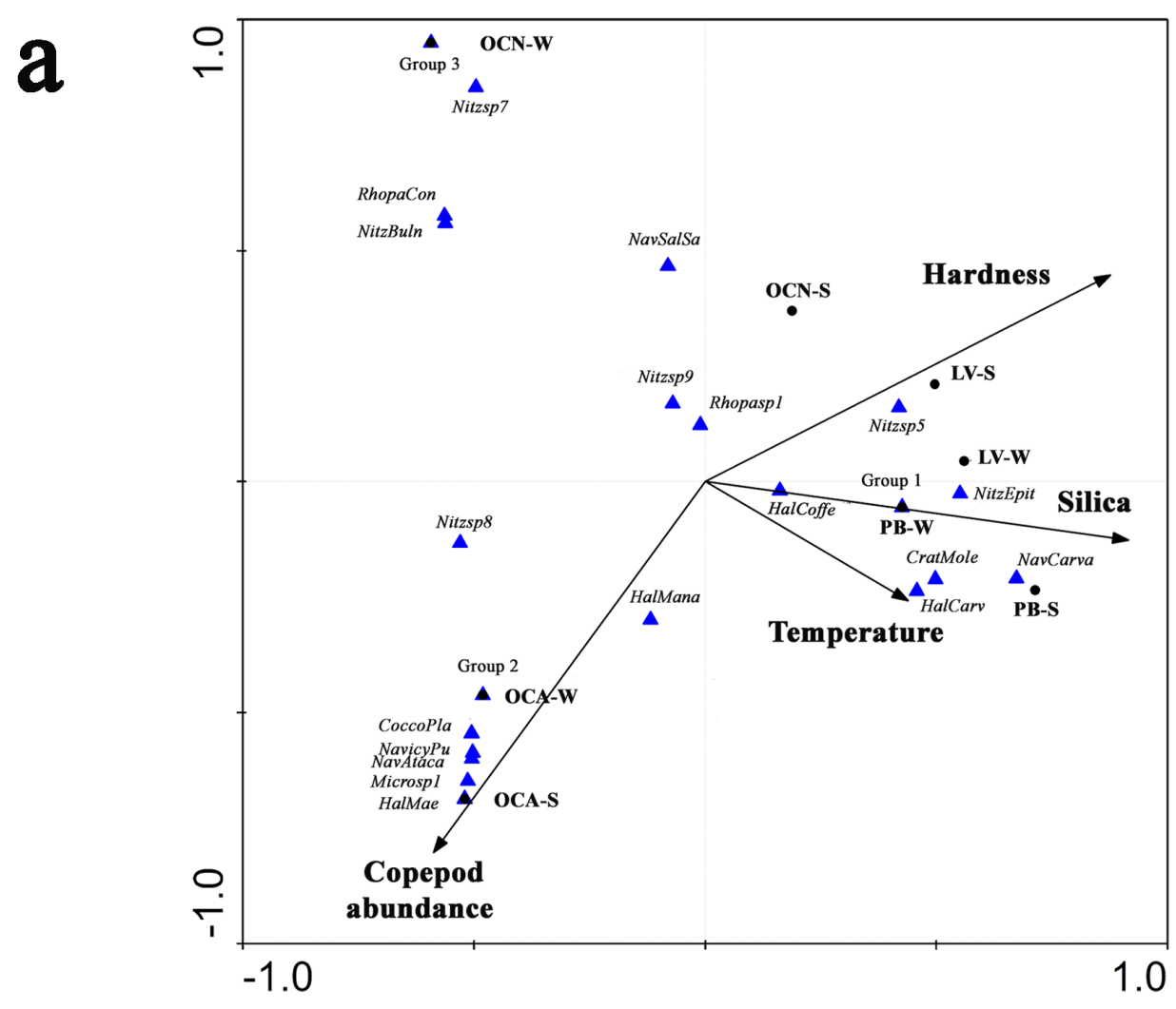

Figure 5. Canonical Correspondence Analysis (CCA) triplot for: (a) diatom community, sites and four variables; Total hardness (Hardness), Dissolved silica (Silica), Temperature and Copepod abundance. Diatom taxa included in Group 1, 2 and 3 are explained in the text. (b) invertebrate community, sites and three variables: Total hardness (Hardness), Diatom richness and Nitrate. Taxa codes are listed in Supplementary Material - Tables SI and SII. Codes for sites as in Fig. 2.

b

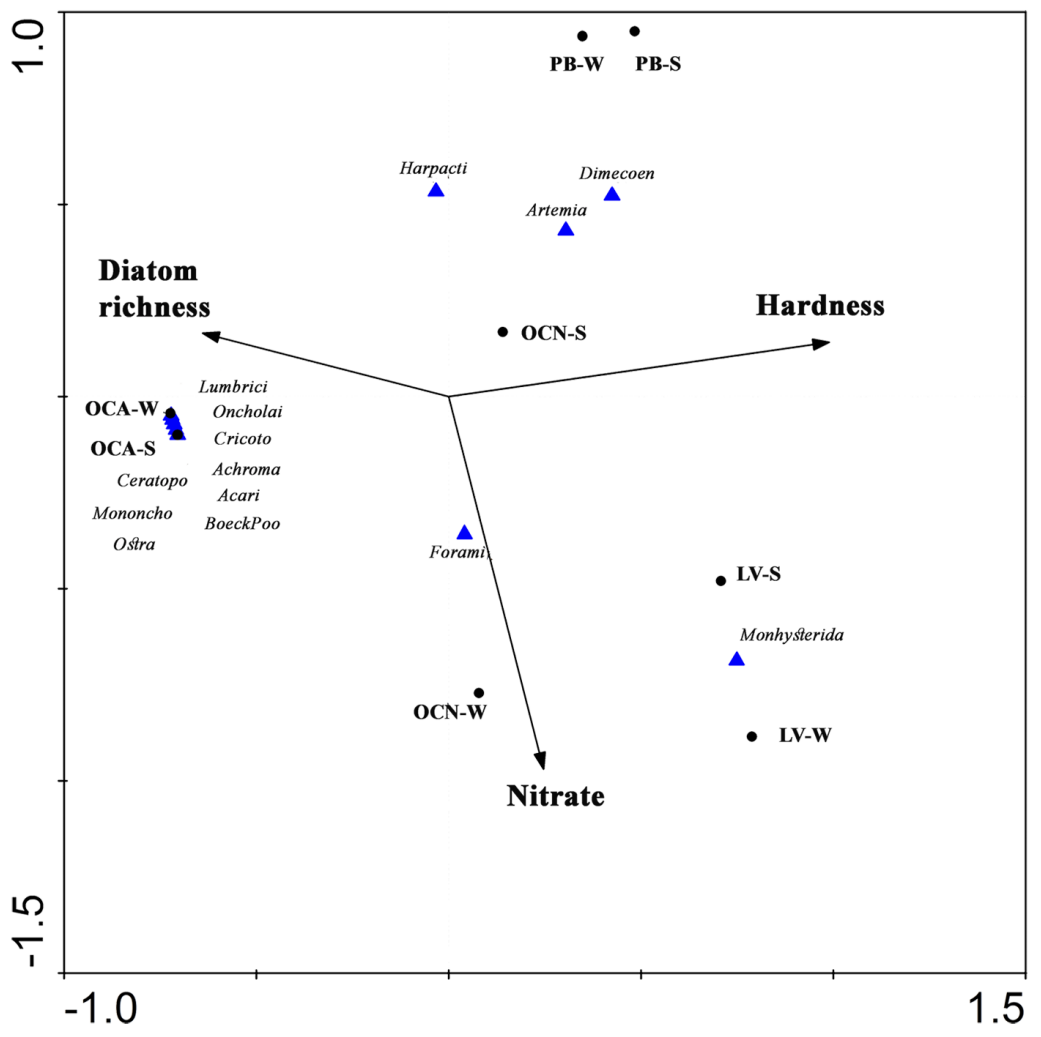


higher depths to become stratified, and, since they have lower density than high saline waters, less wind energy is required for mixing the water column, especially if the lake is exposed to wind. In shallow environments, the exposure to considerable wind allows the water column to be mixed to the bottom, a condition called polymixis (Hammer, 1986). This could be the case of $L V$ and $P B$, the latter had the greatest surface area of the wetlands analyzed, 2.5 meters of maximum depth, and displayed homogeneous thermal and saline vertical profiles.

On the other hand, the strong stratification of OCN during winter that persisted until summer, although less markedly, could be attributed to meromixis. In a saline meromictic lake, part of the water column fails to circulate through the rest of the lake due to a difference in water densities, which is an effect of a higher concentration of dissolved substances in the bottom (Hammer 1986). According to Wetzel (2001), of the many factors that can produce this type of stratification, a variant of ectogenic meromixis is found in many saline lakes of arid regions, and is produced by the subsurface inflow of saline and/or geothermal water to the lake. This can produce meromictic stratification, with warmer and more saline waters underlying cooler and less saline superficial water layers. Due to the volcanic influence of the study area, the heat from subsurface geothermal sources could be a possible explanation for the thermal condition of this environment, like it was proposed by Drago (1989) for volcanic lakes in Antarctica. Further studies are necessary to better understand this phenomenon.

With respect to nutrients, low TP values had been reported for other saline lakes of the Andean Altiplano (Dib et al. 2009, Demergasso et al. 2010). According to Hammer (1986), this could be related to the accumulation and storage of phosphorus by aquatic plants (bacteria, algae and macrophytes) behind their immediate physiological needs. Nitrate was the main form of inorganic nitrogen in the wetlands analyzed, and showed great variation at each site. Unfortunately, data on water nutrients content in high altitude saline lakes are scarce, or not comparable with the values we found in our study. According to Dorador et al. (2008), salt flats located in the Andean Altiplano can have high nutrient concentrations, especially at the most saline sites. Although it has not been analyzed in this paper, nitrification - the biological oxidation of the most reduced form of nitrogen (ammonia) to nitrite and nitrate could probably be associated with the nutrient content we found in the wetlands of the Salar de Antofalla. This process is active in high altitude saline lakes and it is mediated by a diverse community of bacteria and archaeal microorganisms, as reported by several authors in wetlands of the Chilean and Argentinian Altiplano (Dorador et al. 2008, Farias et al. 2013, Molina et al. 2018).

\section{Diatom community}

The NMS ordination showed that, in each wetland studied, the diatom community composition was similar during all seasons, except for summer, where diatom richness decreased. Besides, conductivity values where higher in summer compared to cooler seasons of the year. Evaporation-crystallization processes regulate the hydrochemistry of high altitude saline lakes of the Puna region (Drago \& Quirós 1996); hence increased summer water temperatures (up to $25^{\circ} \mathrm{C}$ ) can lead to a saline concentration of the water in these lakes (Hammer 1986). Several authors also found a negative correlation between algal richness and increasing salinity, since diversity is limited to halotolerant species (Hammer 1986, Williams et al. 1990, Larson \& Belovsky 2013). 
Most of the diatom taxa analyzed in the aquatic environments of the Salar de Antofalla had been reported for high altitude saline wetlands of the Puna Altiplano of Bolivia and Chile (Alvarez-Blanco et al. 2011, Angel et al. 2018), and also for high altitude wetlands in Catamarca (Maidana \& Seeligmann 2006, 2015).

Multivariate analysis showed that of the 14 chemical and 2 biotic variables tested, only two, water hardness and copepods abundance, were selected as the main factors that explained most of the variation in diatom community composition and structure. According to ServantVildary \& Roux (1990), strong modifications of the diatom flora of 13 high altitude lakes of Bolivia were explained by the salinity only when it crossed the limit between fresh-oligohaline to meso-hyperhaline conditions (around $2 \mathrm{~g} / \mathrm{l}$ ). Within these limits, diatom flora changes were better explained by other parameters, like ionic composition. This could probably be the case for the wetlands studied, where, with the exception of the mesohaline OCA, the range of salinity of the other sites analyzed is relatively short, and it belonged to the hyperhaline class (>50 $\mathrm{g} / \mathrm{l}$ ). Hardness and other related variables, such as cation concentration, were also important in influencing diatom species composition of lakes from Costa Rica, where those environments with low values of hardness tended to have greater diatom diversity (Haberyan et al. 1997), as we found in our study. Although it is known that ionic composition affects diatom ecology, either directly (e.g. via their influence on physiological processes) and/or indirectly (e.g. via their influence on biogeochemical cycles), the actual mechanisms by which these parameters influence diatom community structure in saline lakes are yet not well understood (Saros \& Fritz 2000).

The ecological preferences of most diatoms recorded in high altitude lakes are poorly known. Some species, like H. coffeaeformis, are common taxa found in brackish to highly saline environments in subtropical-tropical and arid areas, like the salt flats of the South American Altiplano (Angel et al. 2016), although they are able to support a wide salinity range (Blinn 1993, Blinn et al. 2004). Halamphora coffeaeformis, Navicula salinicola var. salinicola and Denticula sp. 1 were the only diatom taxa common to the four wetlands. The epiphytic Cocconeis placentula is an euryhaline species which can adapt itself to a wide range of salinities (Davies 2002), from brackish and saline waters to freshwater water bodies colonized by macrophytes (Angel et al. 2018). In our study, this species was only found in the mesohaline OCA, together with other taxa exclusive of this site, like Navicula atacamana and N. parinacota, which had also been reported for high altitude mesohaline waters (Seeligmann \& Maidana 2013). One of the most distinctive characteristic of OCA is that its substrate is covered with submerged macrophytes. The environmental heterogeneity generated by aquatic plants may contribute to the species diversity in this site, since more niches are available for species exploiting different resources, as stated in the 'habitat heterogeneity hypothesis' (MacArthur \& MacArthur 1961, MacArthur \& Wilson 1967).

According to our results, copepod abundance also influenced diatom community composition. Copepods represent an important fraction of the crustacean fauna in high altitude saline lakes (Locascio de Mitrovich et al. 2005). Harpacticoid copepods feed on a wide variety of items, including epipelic and epiphytic diatoms, phytoflagellates and bacteria (De Troch et al. 2005). In the case of planktonic calanoids, like Boeckella sp., the diet includes both planktonic and benthonic cyanobacteria, diatoms, green algae, and rotifers (Kleppel 1993, Burns \& Hegarty 1994, Modenutti et al. 1998, Almada et 
al. 2004). In our study, the relative frequencies of some diatom taxa in OCA were positively correlated with copepod abundance. This could suggest that copepod grazing on benthic diatoms is not an important factor to control diatom abundance in this site. Frau et al. (2015) reported a similar positive correlation between abundance of microcrustaceans and algal groups (Chlorophyceae and Euglenophyceae) in other high altitude mesohaline lakes of Catamarca. However, further studies on the gut content of the copepod fauna from these sites are necessary to better understand the relation between copepod and diatom abundances.

\section{Invertebrate community}

Invertebrate taxa richness did not correlate significantly with any of the variables measured in the field. However, the hypersaline wetlands had lower richness values than the mesohaline site. This is probably attributable, for the most part, to the low tolerance to increasing salt concentration of many aquatic taxa, and it has been reported for zooplankton assemblages (Hammer 1986, De los Ríos 2010, Echaniz et al. 2012, Vignatti et al. 2012, Larson \& Belovsky 2013, Frau et al. 2015), and zoobenthic communities in saline lakes (Dejaux 1993, Williams et al. 1995). As with diatoms, the mesohaline OCA accounted for the highest taxa richness of benthonic and planktonic invertebrates. According to Waterkeyn et al. (2008), aquatic vegetation is an important factor influencing invertebrate community structure, presumably because the vegetation creates structural heterogeneity, and it can provide refuge and food resources.

Regarding the fauna composition, most of the taxa registered in the wetlands analyzed are common in saline aquatic environments. In the benthos, brine flies (Diptera, Ephydridae) usually dominate the macroinvertebrate fauna in salt springs and lakes, and tolerate high salinity, high temperatures, and low concentrations of dissolved oxygen (Hammer 1986, Stephens 1990, Foote 1995), and both larvae and adults mainly feed on mats composed of bacteria and algae (Foote 1995). In our study, Dimecoenia sp was the only invertebrate common to the four wetlands.

Nematodes were well represented in the wetlands and accounted for the highest taxa richness, with four taxa registered, three of them coexisting in OCA. Although studies on extremophile nematode taxa remain scarce, new nematode species living in hyperhaline environments have been recently described, and an unexpected nematode diversity in extreme environments has been observed (Gagarin \& Gusakov 2012, D'Almeida et al. 2019, Shih et al. 2019). Some genera we registered in the Salar de Antofalla have been reported in sediments of saline aquatic environments, such as Mononchoides sp. (Shih et al. 2019), and Oncholaimus sp. (Gagarin \& Gusakov 2012).

The benthic fauna of OCA was quite distinctive and dominated by Lumbricillus sp. (Oligochaeta), Cricotopus sp. (Chironomidae), and harpacticoid copepods, in agreement with taxa reported by other authors in mesohaline lakes of the Bolivian Altiplano (Dejaux 1993, Williams et al. 1995).

Regarding zooplankton, large-sized crustaceans were dominant, as expected in fishless lakes (Gutierrez et al. 2018). The halophilic anostracan Artemia sp. (either complete adult individuals, nauplii or cuticle fragments) was registered in three of four sites, although PB was the only wetland where this crustacean population was abundant year-round, and ovigerous females were especially dominant during the warmer months. The occurrence and biogeographic distribution of Artemia sp. populations in Argentinian saline lakes have been reviewed by Amat et al. (2004) and Cohen (2012), and to the best of our knowledge, this is 
the first report on Artemia sp. for high altitude saline lakes in the Catamarca province.

Another main component of zooplankton was the calanoid Boeckella poopoensis registered during the four seasons and exclusively in OCA. Populations of this copepod had a bright red pigmentation, as it has been reported by other authors for high altitude lakes (Frau et al. 2015), which possibly represents an adaptation for protection to UV exposure (Persaud et al. 2007). This species is a common component of zooplankton in saline lakes of central Argentina (Echaniz et al. 2006, 2012, Vignatti et al. 2012, Battauz et al. 2013), and it was reported for high altitude mesohaline lakes in Catamarca (Locascio de Mitrovich 2005, Frau et al. 2015). The non-coexistence of Boeckella and Artemia in the wetlands of the Salar de Antofalla is in agreement with several reports on the South American Altiplano (Hurlbert et al. 1984, 1986, Bayly 1993, Williams et al. 1995, De los Ríos 2005), where both crustaceans apparently have different salinity range preferences. Boeckella poopoensis mostly occurs in waters with salinities between 5 and $90 \mathrm{~g} / \mathrm{l}$, while Artemia sp. predominates in salinities greater than $90 \mathrm{~g} / \mathrm{l}$. Moreover, some authors stated that B. poopoensis adults predate on Artemia nauplii in low salinity (Hurlbert et al. 1986, Williams et al. 1998), and this could be another reason why both crustaceans do not coexist.

Our results from CCA suggested that water hardness was the main environmental factor significantly influencing invertebrate community assemblages in the wetlands analyzed. Few studies examine the relation between hardness and invertebrate distribution in saline lakes. Bos et al. (1996) reported that zooplankton composition of several lakes in Canada was related not only to conductivity but also to ionic composition. Populations of Artemia franciscana, for example, were related to meso-hypersaline waters that are high in $\mathrm{Mg}, \mathrm{Ca}$, and sulphate, and have a low $\mathrm{pH}$.

Finally, diatom taxa richness and nitrate content were also selected as predictors of the variability in invertebrate communities, although they were statistically not significant to the ordination model. Therefore, higher frequencies of different invertebrate taxa were associated with higher diatom richness taxa in OCA. Feeding habits of the aquatic fauna reported for this mesohaline site mostly include benthic diatom consumers, like oligochaetes, some nematoda, ostracods and copepods, which can graze selectively upon algae communities (Giere 2009). This could suggest that a high diatom taxa richness, and, consequently, a better offer of diatoms types and sizes, could be a bottomup factor controlling invertebrate frequencies, although specific studies should be conducted in order to analyze this relation.

\section{CONCLUSIONS}

Saline wetlands, located at the same altitude, showed spatial and temporal heterogeneity of physical and chemical conditions, mainly related to salinity (from mesohaline to hyperhaline), dissolved oxygen content and ionic composition of the water. Each site represented a particular niche for the aquatic biota, which was distributed according to the environmental variables. Fortytwo benthic diatom and fifteen benthic and planktonic invertebrate taxa were registered in the four high altitude saline wetlands analyzed. We highlight the set of features registered in the mesohaline Ojo de Campo Azul, which was characterized by a distinctive aquatic biota and the highest biological richness of the wetlands analyzed. Among the variables studied, water hardness explained most of the variation in the composition of diatoms and invertebrates, 
suggesting that the ionic content of water may be a significant determinant for aquatic communities distribution in extreme mesohyperhaline environments located at the same altitude. Further multidisciplinary research, involving geological, chemical, microbiological, genetic, and other approaches, are of great importance for high altitude saline wetlands, like the ones we studied, since current anthropogenic activities in the area, such us lithium exploring and tourism, may affect these unique and still pristine aquatic systems and the biota inhabiting them.

\section{Acknowledgments}

We thank the Kolla Atacameña Community of Antofalla for their company and participation during the field campaigns. We also thank Mr. Luis Ahumada for his logistic and collaboration during sampling. Financial support for this work was provided by the National Scientific and Technical Research Council (CONICET) and National University of Catamarca (UNCA), under PIO project 15920150100017CO.

\section{REFERENCES}

ALBARRACÍN VH, PATHAK GP, DOUKI T, CADET J, BORSARELLI CD, GÄRTNER W \& FARÍAS ME. 2012. Extremophilic acinetobacter strains from high-altitude lakes in Argentinean Puna: remarkable UV-B resistance and efficient DNA damage repair. Orig Life Evol Biosph 42: 201-221.

ALCORLO P, BALTAMIS A \& MONTES C. 2001. Food-web structure in two shallow salt lakes in Los Monegros (NE Spain): energetic vs. dynamic constraints. Hydrobiologia 466: 307-316.

ALMADA P, ALLENDE L, TELL G \& IZAGUIRRE I. 2004. Experimental evidence of the grazing impact of Boeckella poppei on phytoplankton in a maritime Antarctic lake. Polar Biol 28: 39-46.

ÁlVAREZ-BLANCO I, CEJUDO-FIGUEIRAS C, DE GODOS I, MUÑOZ R \& BLANCO S. 2011. Las diatomeas de los salares del altiplano boliviano: singularidades florísticas. Bol R Soc Esp Hist Nat Secc Biol 105: 67-82.

ALONSO RN. 2006. Ambientes evaporíticos continentales de Argentina. Temas de la geología Argentina I (2)
Ambientes Evaporíticos. Insugeo, Serie Correlación Geológica, 21: 155-170.

AMAT F, COHEN RG, HONTORIA F \& NAVARRO JC. 2004. Further evidence and characterization of Artemia franciscana (Kellogg, 1906) populations in Argentina. J Biogeogr 31: 1735-1749.

ANGEL A, VILA I \& HERRERA V. 2016. Extremophiles: photosynthetic systems in a high-altitude saline basin (Altiplano, Chile). Int Aquat Res 8:91-108.

ANGEL A, VILA I, DÍAZ C, MOLINA X \& SEPÚLVEDA P. 2018. Geothermal diatoms: seasonal variability in the El Tatio geothermal field (Altiplano, Chile). Adv Microbiol 8: 211-234.

APHA. 2012. Standard Methods for the Examination of Water and Wastewater. $22^{\text {nd }}$ ed., American Public Health Association. Washington, DC, United Kingdom.

ARCMAP $^{\text {TM }}$ 10.6.1. 2019. ArcGIS ${ }^{\circledR}$. Geographical Information Systems (GIS). Esri (Environmental Systems Research Institute). California. United States of America.

AUGE M, WETTEN C, BAUDINO G, BONORINO G, GIANNI R, GONZÁLEZ N \& SISUL A. 2006. Hidrogeology of Argentina. Bol Geol Min 117: 7-23.

BATTARBEE RW. 1986. Diatom analysis. In: Berglund BE (Ed), Handbook of Holocene palaeoecology and palaeohydrology, John Wiley \& Sons Ltd, Chichester, p. 527-570.

BATTAUZ YS, JOSE SB, PAGGI JC, ROMANO M \& BARBERIS I. 2013. Zooplankton characterisation of Pampean saline shallow lakes, habitat of the Andean flamingoes. J Limnol 72: 531-542.

BAYLY IAE. 1992. Fusion of the genera Boeckella and Pseudoboeckella (Copepoda) and revision of their species from South America and sub-Antarctic islands. Rev Chil Hist Nat 65: 17-63.

BAYLY IAE. 1993. The fauna of athalassic saline waters in Australia and the Altiplano of South America: comparisons and historical perspectives. Hydrobiologia 267: 225-231.

BAYLY IAE. 1995. Distinctive aspects of the zooplankton of large lakes in Australasia, Antarctica and South America. Mar Freshw Res 46: 1109-1120.

BLINN DW. 1993. Diatom community structure along physicochemical gradients in saline lakes. Ecology 74 : 1246-1263.

BLINN DW, HALSE SA, PINDER AM, SHIEL RJ \& MCRAE JM. 2004. Diatom and micro-invertebrate communities and environmental determinants in the western Australian 
wheatbelt: A response to salinization. Hydrobiologia 528: 229-248.

BOS DG, CUMMING BF, WATTERS CE \& SMOL JP. 1996. The relationship between zooplankton, conductivity and lake- water ionic composition in 111 lakes from the Interior Plateau of British Columbia, Canada. Int J Salt Lake Res 5: 1-15.

BRINKHURST RO. 1971. A guide for the identification of British aquatic Oligochaeta. Freshwater Biological Association. Scientific Publication $n^{\circ} 22,2^{\text {nd }}$ ed.

BRUNO MC, REID JW \& PERRY SA. 2005. A list and identification key for the freshwater, free-living copepods of Florida (U.S.A.). J Crustacean Biol 25: 384-400.

BURNS CW \& HEGARTY B. 1994. Diet selection by copepods in the presence of cyanobacteria. J Plankton Res 16:1671-1690.

CAZIANI SM, ROCHA OLIVIO O, RODRÍGUEZ RAMÍREZ E, ROMANO M, DERLINDATI EJ, TÁLAMO A \& SOSA H. 2007. Seasonal distribution, abundance, and nesting of Puna, Andean, and Chilean Flamingos. The Condor 109: 276-287.

CAZIANI SM \& DERLINDATI E. 2000. Abundance and habitat of High Andes Flamingos in Northwestern Argentina. Waterbirds 23(Special): 121-133.

CLARKE KR, GORLEY RN, SOMERFIELD PJ \& WARWICK RM. 2014. Change in Marine Communities, $3^{\text {rd }}$ ed., PRIMER-E Ltd, Plymouth.

COHEN RS. 2012. Review of the biogeography of Artemia Leach, 1819 (Crustacea: Anostraca) in Argentina. Int J Artemia Biology 2: 9-23.

COLE GA. 1983. Textbook of Limnology, $3^{\text {rd }}$ ed., Mosby Company, Missouri, USA, 405 p.

D'ALMEIDA RE, GARCÍA ME, PÉREZ MF, FARÍAS ME \& DIB JR. 2019. Novel nematode species in living stromatolites in the Andean Puna. Invert Zool 16: 211-218.

DAVIES SJ, METCALFE SE, CABALLERO ME \& JUGGINS S. 2002. Developing diatom-based transfer functions for Central Mexican lakes. Hydrobiologia 467: 199-213.

DEJAUX C. 1993. Benthic invertebrates of some saline lakes of the Sud Lipez region, Bolivia. Hydrobiologia 27: 257-267.

DE LOS RÍOS P. 2005. Richness and distribution of zooplanktonic crustacean species in Chilean Andes mountains and southern Patagonia shallow ponds. Pol J Environ Stud 14: 817-822.

DE LOS RÍOS P. 2010. Crustacean zooplankton communities in Chilean inland waters. Crustac Monogr 12: 1-109.
DEMERGASSO C, DORADOR C, MENESES D, BLAMEY J, CABROL N, ESCUDERO L \& CHONG G. 2010. Prokaryotic diversity pattern in high altitude ecosystems of the Chilean Altiplano. J Geophys Res 115: G00D09.

DE TROCH M, STEINARSDÓTTIR MB, CHEPURNOV V \& ÓLAFSSON E. 2005. Grazing on diatoms by harpacticoid copepods: species-specific density-dependent uptake and microbial gardening. Aquat Microb Ecol 39: 135-144.

DIB JR, WEISS A, NEUMANN A, ORDOÑEZ O, ESTÉVEZ MC \& FARÍAS ME. 2009. Isolation of bacteria from remote high altitude Andean wetlands able to grow in the presence of antibiotics. Recent Patents on Anti-Infective Drug Discovery 4: 66-76.

DORADOR C, BUSEKOW A, VILA I, IMHOFF JF \& WITZEL KP. 2008. Molecular analysis of enrichment cultures of ammonia oxidizers from the Salar de Huasco, a high altitude saline wetland in northern Chile. Extremophiles 12: 405-414.

DRAGO EC. 1989. Thermal summer characteristics of lakes and ponds on Deception Island, Antarctica. Hydrobiologia 184: 51-60.

DRAGO EC \& QUIRÓS R. 1996. The hydrochemistry of the inland waters of Argentina: a review. Int J Salt Lake Res 4: 315-325.

ECHANIZ SA, VIGNATTI AM, DE PAGGI SJ, PAGGI JC \& PILATI A. 2006. Zooplankton seasonal abundance of South American saline shallow lakes. Int Rev Hydrobiol 91: 86-100.

ECHANIZ SA, VIGNATTI AM, CABRERA GC \& DE PAGGI SBJ. 2012. Zooplankton richness, abundance and biomass of two hypertrophic shallow lakes with different salinity in central Argentina. Biota Neotrop 12: 41-48.

FARÍAS ME, RASCOVAN N, TONEATTI DM, ALBARRACÍN VH, FLORES MR, POIRÉ DG, COLLAVINO MM, AGUILAR OM, VAZQUEZ MP \& POLERECKY L. 2013. The Discovery of stromatolites developing at $3570 \mathrm{~m}$ above sea level in a high-altitude volcanic Lake Socompa, Argentinean Andes. Plos One 8 E53497.

FERNÁNDEZ-ZENOFF MV, DIB JR, NEUMANN A, ESTÉVEZ MC \& FARÍAS ME. 2015. Water and flamingo feces bacterial communities from High- Altitude Andean Lakes under selective antibiotic pressure studied by PCRDGGE analyses. In Prof. Maria Cristina Ossiprandi (Ed), Antimicrobial Resistance - An Open Challenge. IntechOpen DOI: 10.5772/61967.

FERNÁNDEZ H \& DOMíngUEZ E. 2001. Guía para la determinación de los artrópodos bentónicos Sudamericanos. Secretaría de Ciencia y Técnica. Editorial Universitaria de Tucumán, 282 p. 
FLORES MR, ORDOÑEZ O, MALDONADO MJ \& FARÍAS ME. 2009. Isolation of UV-B resistant bacteria from two high altitude Andean lakes (4,400 m) with saline and nonsaline conditions. J Gen Appl Microbiol 55: 447-458.

FOOTE BA. 1995. Biology of shore flies. Annu Rev Entomol 40: 417-442.

FRAU D, BATTAUZ Y, MAYORA G \& MARCONI P. 2015. Controlling factors in planktonic communities over a salinity gradient in high-altitude lakes. Ann Limnol - Int J Lim 51: 261-272.

GAGARIN V \& GUSAKOV V. 2012. Oncholaimus rivalis sp. $n$. (Nematoda, Enoplida) from highly mineralized rivers of Lake El'ton basin, Russia. Int J Nematol 22: 13-20.

GARCÍA RF, ROCHA FASOLA V, MOYA RUIZ FA \& TÁLAMO E. 2013. Exploración y Explotación de Salmueras Enriquecidas en Litio y Potasio en Salares de la Puna Argentina. In: Gonzalez et al. (Eds), Temas actuales de la hidrología subterránea. Editorial de la Universidad Nacional de La Plata (Edulp), Buenos Aires, p. 303-311.

GIERE O. 2009. Meiofauna Taxa: A systematic account. In: Meiobenthology. Springer, Berlin, Heidelberg, p. 103-234.

GUTIERREZ MF, TAVSANOGLU UN, VIDAL N, YU J, TEIXEIRADE MELLO F, CAKIROGLU AI, HE H, LIU Z \& JEPPESEN E. 2018. Salinity shapes zooplankton communities and functional diversity and has complex effects on size structure in lakes. Hydrobiologia https://doi.org/10.1007/ s10750-018-3529-8.

GOMEZ FJ, KAH LC, BARTLEY JK \& ASTINIR A. 2014. Microbialites in a high-altitude Andean Lake: multiple controls on carbonate precipitation and lamina accretion. Palaios 29: 233-249.

GOMEZ FJ, MLEWSKI C, BOIDI FJ, FARÍAS ME \& GERARD E. 2018. Calcium carbonate precipitation in diatom-rich microbial mats: The Laguna Negra hypersaline lake, Catamarca, Argentina. J Sediment Res 88: 727-742.

HABERYAN K, HORN SP \& CUMMING BF. 1997. Diatom assemblages from Costa Rican lakes: an initial ecological assessment. J Paleolimnol 17: 263-274.

HAMMER $\varnothing$, HARPER DAT \& RYAN PD. 2001. PAST: Paleontological Statistics Software Package for Education and Data Analysis. Palaeontol Electronica 4: 1-9.

HAMMER UT. 1986. Saline Lake Ecosystems of the World, Junk Publishers, Dordrecht, Holland, 613 p.

HELBLING EW, FARÍAS ME, FERNÁNDEZ-ZENOFF MV \& VILLAFAÑE VE. 2006. In situ responses of phytoplankton from the subtropical Lake La Angostura (Tucumán, Argentina) in relation to solar ultraviolet radiation exposure and mixing conditions. Hydrobiologia 559: 123-134.

HERNÁNDEZ KL, YANNICELLI B, OLSEN LM, DORADOR C, MENSCHEL EJ, MOLINA V, REMONSELLEZ F, HENGST MB \& JEFFREY WH. 2016. Microbial activity response to solar radiation across contrasting environmental conditions in Salar de Huasco, northern Chilean Altiplano. Front Microbiol 7:1857. doi:10.3389/fmicb.2016.01857.

HURLBERT SH, LOAYSA W \& MORENO T. 1986. Fish-flamingoplankton interactions in the Peruvian Andes. Limnol Oceanog 31: 457-468.

HURLBERT SH, LÓPEZ M \& KEITH JO. 1984. Wilson's phalarope in the central Andes and its interaction with the Chilean flamingo. Rev Chil Hist Nat 57: 47-57.

ILTIS A, RISACHER F \& SERVANT-VILDARY S. 1984. Contribution a l'etude hydrobiologique des lacs sales du sud del'Altiplano bolivien. Rev Hydrobiol Trop 17: 259-273.

INTERNATIONAL STANDARD ISO14911. 1998. Water quality - Determination of dissolved $\mathrm{Li}+, \mathrm{Na}+, \mathrm{NH}_{4}+, \mathrm{K}+, \mathrm{Mn} 2+$, $\mathrm{Ca} 2+, \mathrm{Mg} 2+, \mathrm{Sr} 2+$ and $\mathrm{Ba} 2+$ using ion chromatography Method for water and waste water.

IUCN. 2019. The International Union for Conservation of Nature Red List of Threatened Species. Version 2019-1. Https://Www.lucnredlist.Org

IZQUIERDO A, GRAU R, CARILLA J. \& CASAGRANDA E. 2015. Side effects of green technologies: the potential environmental costs of lithium mining on high elevation Andean wetlands in the context of climate change. GLP News 12: 53-56.

IZQUIERDO A, FOGUET J \& GRAU H. 2016. "Hidroecosistemas" de la Puna y Altos Andes de Argentina. Acta Geol Lillo 28: 390-402.

JAKHER GR, BHARGAVA SC \& SINHA RK .1990. Comparative limnology of Sambhar and Didwana lakes (Rajasthan, NW India) Hydrobiologia 197: 245-256.

KLEPPEL GS. 1993. On the diets of calanoid copepods. Mar Ecol Prog Ser 99: 183-195.

KRAEMER B, ADELMANN D, ALTEN M, SCHNURR W, ERPENSTEIN K, KIEFER E \& GÖRLER K. 1999. Incorporation of the Paleogene foreland into the Neogene Puna plateau: The Salar de Antofalla area, NW Argentina. J S Am Earth Sci 12:157-182. doi: https://doi.org/10.1016/S0895-9811(99)00012-7.

KRAMER K. 2000. Diatoms of Europe. Vol. 1: The Genus Pinnularia. ARG Gantner Verlag. Kommanditgesellschaft, Königstein, 1-703. http://dx.doi. org/10.1023/A:1008914531485 
LANGE-BERTALOT H. 2000. Iconographia Diatomologica. Diatoms of the Andes. Vol. 9. ARG Gantner Verlag. Koeltz Scientific Books, Koenigstein.

LANGE-BERTALOT H. 2001. Navicula sensu stricto, 10 genera separated from Navicula sensu lato, Frustulia. In: LangeBertalot $\mathrm{H}$ et al. (Eds), Diatoms of Europe: diatoms of the European Inland waters and comparable habitats, Gantner Publishers, p. 526.

LARSON CA \& BELOVSKY GE. 2013. Salinity and nutrients influence species richness and evenness of phytoplankton communities in microcosm experiments from Great Salt Lake, Utah, USA. J Plankton Res 35: 1154-1166.

LEPŠ J \& ŠMILAUER P. 2003. Multivariate Analysis of Ecological Data using CANOCO. Cambridge University Press, p. 267.

LETERME SC, PRIME E, MITCHELL J, BROWN MH \& ELLIS AV. 2013. Diatom adaptability to environmental change: a case study of two Cocconeis species from high-salinity areas. Diatom Res 28:29-35.

LEVKOV Z. 2009. Diatoms of Europe 5. Amphora Sensu Lato. Germany: ARG. Gantner Verlag K. G, p. 926.

LEVKOV Z, METZELTIN D \& PAVLOV A. 2013. Diatoms of Europe, Diatoms of the European Inland waters and comparable habitats. Luticola and Luticolopsis. Germany: ARG. Gantner Verlag, K. G, p. 698.

LOCASCIO DE MITROVICH C, DE GAMUNDI AV, JUÁREZ J \& CERAOLO M. 2005. Características limnológicas y zooplancton de cinco lagunas de la Puna - Argentina. Ecol Boliv 40: 10-24.

MACARTHUR RH \& MACARTHUR JW. 1961. On bird species diversity. Ecology 42: 594-598.

MACARTHUR RH \& WILSON EO. 1967. The theory of island biogeography. Princeton University Press, Princeton.

MAIDANA NI \& SEELIGMANN C. 2006. Diatomeas (Bacillariophyceae) de ambientes acuáticos de altura de la provincia de Catamarca, Argentina. II. Bol Soc Argent Bot 41: 1 - 13.

MAIDANA NI \& SEELIGMANN C. 2015. Diatomeas (Bacillariophyceae) en humedales de altura de la provincia de Catamarca, Argentina. III. Bol Soc Argent Bot 50: 447-466.

MÁRQUEZ-GARCÍA M, VILA I, HINOJOSA LF, MÉNDEZ MA, CARVAJAL JL \& SABANDO MC. 2009. Distribution and seasonal fluctuations in the aquatic biodiversity of the southern Altiplano. Limnologica 39: 314-318.
MIRANDE V \& TRACANNA BC. 2009. Estructura y controles abióticos del fitoplancton en humedales de altura. Ecol Austral 19:119-128.

MIRANDE V \& TRACANNA BC. 2017. Algas verdes y euglénidos de la Puna argentina. Lilloa 54: 210-228.

MODENUTTI BE, BALSEIRO EG, QUEIMALIÑOS CP, AÑÓN SUÁREZ DA, DIÉGUEZ MC \& ALBARIÑO RJJ. 1998. Structure and dynamics of food webs in Andean lakes. Lakes Reserv Res Manag 3: 179-186.

MOELLER RE, GILROY S, WILLIAMSON CE, GRAD G \& SOMMARUGA R. 2005. Dietary acquisition of photoprotective compounds (mycosporine-like amino acids, carotenoids) and acclimation to ultraviolet radiation in a freshwater copepod. Limnol Oceanogr 50: 427-439.

MOLINA V, DORADOR C, FERNÁNDEZ C, BRISTOW L, EISSLER Y, HENGST M, HERNANDEZ K, OLSEN LM, HARROD C, MARCHANT F, ANGUITA C \& CORNEJO M. 2018. The activity of nitrifying microorganisms in a high-altitude Andean wetland. FEMS Microbiology Ecology 94 doi: 10.1093/femsec/fiy062.

MUÑOZ-PEDREROS A, DE LOS RÍOS P \& MÖLLER P. 2013. Zooplankton in Laguna Lejía, a High-Altitude Andean shallow lake of the Puna in northern Chile. Crustaceana 86: 634-1643.

MUÑOZ-PEDREROS A, DE LOS RÍOS P \& MÖLLER P. 2015. Zooplankton of the Highland Bogs of Putana, a desert wetland of the High Puna, northern Chile. Crustaceana 88: $1235-1244$.

ORDOÑEZ OF, FLORES MR, DIB JR, PAZ A \& FARÍAS ME. 2009. Extremophile culture collection from Andean Lakes: extreme pristine environments that host a wide diversity of microorganisms with tolerance to UV radiation. Microb Ecol 58: 461-473.

OREN A. 2001. The bioenergetic basis for the decrease in metabolic diversity at increasing salt concentrations: implications for the functioning of salt lake ecosystems. Hydrobiologia 466: 61-72.

OREN A. 2009. Microbial diversity and microbial abundance in salt-saturated brines: Why are the waters of hypersaline lakes red? Natural Resources and Environmental Issues 15: 247-255.

PERSAUD AD, MOELLER RE, WILLIAMSON CE \& BURNS CW. 2007. Photoprotective compounds in weakly and strongly pigmented copepods and co-occurring cladocerans. Fresh Biol 52: 2121-2133.

POR FD. 1980. A classification of hypersaline waters, based on trophic criteria. Mar Ecol I: 121-131. 
RAMOS VA. 1999. Las Provincias Geológicas Del Territorio Argentino. Instituto De Geología y Recursos Minerales. Geología Argentina. Anales 29: 41-96.

RASCOVAN N, MALDONADO MJ, VAZQUEZ MP \& FARÍAS ME. 2016. Bioenergetic use of Arsenic in Haloarchaea biofilms from Diamante Lake. Isme J 10: 299-309.

RASUK MC, KURTH D, FLORES R, CONTRERAS M, NOVOA F, POIRÉ D \& FARÍAS ME. 2014. Microbial characterization of a gypsum endoevaporitic ecosystem in Salar de Llamara, Chile. Microb Ecol 68: 483-494.

RASUK MC, FERNÁNDEZ AB, KURTH D, CONTRERAS M, NOVOA F, POIRÉ D \& FARÍAS ME. 2016. Bacterial diversity in microbial mats and sediments from Atacama Desert. Microb Ecol 71: 44-56.

RISHWORTH GM, PERISSINOTTO R \& BIRD MS. 2016. Coexisting living stromatolites and infaunal metazoans. Oecologia 182: 539-545.

ROUND FE, CRAWFORD RM \& MANN DG. 1990. The Diatoms. Biology and Morphology of the Genera. Cambridge University Press, p. 747.

ROUNDS SA, WILDE FD \& RITZ GF. 2013. Dissolved oxygen (ver. 3.0): U.S. Geological Survey Techniques of WaterResources Investigations, book 9, chap. A6, sec. 6.2.

SAROS JE \& FRITZ SC. 2000. Nutrients as a link between ionic concentration/composition and diatom distributions in lakes. J Paleolimnol 23: 449-453.

SCHEIHING R, LABARCA P, SANTIBAÑEZ P, ASENCIO G, CLASING E, \& NESPOLO RF. 2010. A quantitative survey of the aquatic invertebrate community in the "Monumento natural Salar de Surire" on the Chilean Altiplano. J Nat Hist 44: 2917-2928.

SCHMELZ RM \& COLLADO R 2010. A guide to European terrestrial and freshwater species of Enchytraeidae (Oligochaeta). Soil Org 82: 1-176.

SEELIGMANN CT \& MAIDANA NI. 2013. ¿Existen especies de Navicula (Bacillariophyta) exclusivas de ambientes de alta montaña en Argentina? B Soc Argent Bot 48: 421-433.

SEELIGMANN CT, MAIDANA NI \& MORALES EA. 2018. Fragilariaceae (Bacillariophyta) en humedales de altura de Catamarca (Argentina). B Soc Argent Bot 53: 507-519.

SERVANT-VILDARY S \& ROUX M. 1990. Multivariate analysis of diatoms and water chemistry in Bolivian saline lakes. Hydrobiologia 197: 267-290.

SHIH PY, SIHO LEE J, SHINYA R, KANZAKI N, DA SILVA AP, BADROOS JM, GOETZ E, SAPIR A \& STERNBERG PW. 2019. Newly identified nematodes from Mono Lake exhibit extreme arsenic resistance. Curr Biol 29(19): 3339-3344. https://doi. org/10.1016/j.cub.2019.08.024.

SOMMARUGA R. 2001. The role of solar UV radiation in the ecology of alpine lakes. J Photoch Photobio B 62: 35-42.

STEPHENS DW. 1990. Changes in lake levels, salinity and the biological community of Great Salt Lake (Utah, USA), 1847-1987. Hydrobiologia 197: 139-146.

TARJAN AC, ESSER RP \& CHANG SL. 1977. An illustrated key to nematodes found in fresh water. J Water Pollut Control Fed 49: 2318-2337.

TER BRAAK CJF \& ŠMILAUER P. 1998. CANOCO Reference Manual and Canoco Draw for Windows User's Guide: Software for Canonical Community Ordination (Version 4.5). Microcomputer Power, Ithaca.

US EPA. 2015. Test Methods for Evaluating Solid Waste, Physical/Chemical Methods, EPA publication SW 846, Third Edition, Final Updates I (1993), II (1995), IIA (1994), IIB (1995), III (1997), IIIA (1999), IIIB (2005), IV (2008), and $\mathrm{V}(2015)$.

VALERO-GARCÉS BL, DELGADO-HUERTAS A, RATTO N, NAVAS A \& EDWARDS L. 2000. Paleohydrology of Andean saline lakes from sedimentological and isotopic records, northwestern Argentina. J Paleolimnol 24: 343-359.

VIGNATTI AM, PAGGI JC, CABRERA GC \& ECHANIZ SA. 2012. Zooplankton diversity and its relationship with environmental changes after the filling of a temporary saline lake in the semi-arid region of La Pampa, Argentina. Lat Am J Aquat Res 40: 1005-1016.

VOSS R. 2002. Cenozoic stratigraphy of the southern Salar de Antofalla region, northwestern Argentina. Rev Geol Chile 29: 167-190.

WATERKEYN A, GRILLAS P, VANSCHOENWINKEL B \& BRENDONCK L. 2008. Invertebrate community patterns in Mediterranean temporary wetlands along hydroperiod and salinity gradients. Freshwater Biol 53: 1808-1822.

WETZEL RG. 2001. Limnology: lake and river ecosystem. Academic Press, San Diego, p. 1006.

WILLIAMS WD, BOULTON AJ \& TAAFFE RG. 1990. Salinity as a determinant of Salt Lake fauna: a question of scale. Hydrobiologia 197: 257-266.

WILLIAMS WD, CARRICK TR, BAYLY IAE, GREEN J \& HERBST DB. 1995. Invertebrates in salt lakes of the Bolivian Altiplano. Int J Salt Lake Res 4: 65-77.

WILLIAMS WD, DEDECKER P \& SHIELD RK. 1998. The limnology of Lake Torrens, an episodic salt lake of central Australia, with particular reference to unique events in 1989. Hydrobiologia 384: 101-110. 
ZÚÑIGA LR, CAMPOS V, PINOCHET H \& PRADO B. 1991. A limnological reconnaissance of Lake Tebenquiche, Salar de Atacama, Chile. Hydrobiologia 210: 19-24.

\section{SUPPLEMENTARY MATERIAL}

Table SI. Seasonal occurrence (presence: X; absence: -) and richness of benthic diatom taxa in the four high altitude wetlands analyzed in the Salar de Antofalla. F: fall; W: winter; Sp: spring; S: summer. Abbreviated names used in statistical graphs are marked in parenthesis and bold.

Table SII. Seasonal occurrence (presence: X; absence: -) and richness of benthic and planktonic invertebrate taxa in the four high altitude wetlands analyzed in the Salar de Antofalla. F: fall; W: winter; Sp: spring; S: summer. Asterisks ( ${ }^{\star}$ ) show planktonic taxa. Abbreviated names used in statistical graphs are marked in parenthesis and bold.

\section{How to cite}

COLLA MF, LENCINA AI \& FARÍAS ME. 2022. Diatom and Invertebrate Assemblages in High Altitude Saline Wetlands of the Argentinian Puna and their Relation to Environmental Factors. An Acad Bras Cienc 94: e20200070. DOI 10.1590/0001-3765202220200070.

Manuscript received on January 16, 2020;

accepted for publication on July 7, 2020

\section{MARÍA FLORENCIA COLLA}

https://orcid.org/0000-0002-5207-2327

\section{AGUSTINA INÉS LENCINA ${ }^{1}$}

https://orcid.org/0000-0003-2620-5162

MARÍA EUGENIA FARÍAS ${ }^{2}$

https://orcid.org/0000-0002-2771-8915

${ }^{1}$ Centro Regional de Energía y Ambiente para el Desarrollo Sustentable (CREAS-UNCA-CONICET), Laboratorio de Investigaciones Geológicas y Biológicas sobre Humedales, Núñez del Prado 366, 4700, San

Fernando del Valle de Catamarca, Argentina

${ }^{2}$ Planta Piloto de Procesos Microbiológicos Industriales (PROIMI-CONICET), Laboratorio de Investigaciones Microbiológicas de Lagunas Andinas (LIMLA), Avda. Belgrano y Pje. Caseros, 4000, San Miguel de Tucumán, Argentina

Correspondence to: María Florencia Colla

E-mail:flo4bio@gmail.com

\section{Author contributions}

MFC and AIL contributed equally to this work. Both authors obtained the data and analyzed and interpreted the results. MFC wrote the manuscript in consultation with AIL and MEF. MEF directed the research and provided financial support.

(cc) BY 